Article

\title{
Sustainable Carbon Dioxide Photoreduction by a Cooperative Effect of Reactor Design and Titania Metal Promotion
}

\author{
Alberto Olivo ${ }^{1}$ (D), Elena Ghedini ${ }^{1}$, Paolina Pascalicchio ${ }^{1}$, Maela Manzoli ${ }^{2}$ (D), \\ Giuseppe Cruciani ${ }^{3}$ and Michela Signoretto ${ }^{1, *}$ (iD \\ 1 CATMAT Lab, Department of Molecular Sciences and Nanosystems, Ca' Foscari University Venice and \\ Consortium INSTM, RU of Venice, Via Torino 155, 30172 Venezia, Italy; alberto.olivo@unive.it (A.O.); \\ gelena@unive.it (E.G.); paolina.pascalicchio@outlook.it (P.P.) \\ 2 Department of Drug Science and Technology \& NIS Interdepartmental Centre, University of Turin, \\ Via P. Giuria 7, 10125 Turin, Italy; maela.manzoli@unito.it \\ 3 Department of Physics and Earth Sciences, University of Ferrara, Via G. Saragat 1, I-44122 Ferrara, Italy; \\ cru@unife.it \\ * Correspondence: miky@unive.it; Tel.: +39-041-234-8650
}

Received: 21 December 2017; Accepted: 18 January 2018; Published: 22 January 2018

\begin{abstract}
An effective process based on the photocatalytic reduction of $\mathrm{CO}_{2}$ to face on the one hand, the crucial problem of environmental pollution, and, on the other hand, to propose an efficient way to product clean and sustainable energy sources has been developed in this work. Particular attention has been paid to the sustainability of the process by using a green reductant (water) and $\mathrm{TiO}_{2}$ as a photocatalyst under very mild operative conditions (room temperature and atmospheric pressure). It was shown that the efficiency in carbon dioxide photoreduction is strictly related to the process parameters and to the catalyst features. In order to formulate a versatile and high performing catalyst, $\mathrm{TiO}_{2}$ was modified by oxide or metal species. Copper (in the oxide $\mathrm{CuO}$ form) or gold (as nanoparticles) were employed as promoting metal. Both photocatalytic activity and selectivity displayed by $\mathrm{CuO}-\mathrm{TiO}_{2}$ and $\mathrm{Au}-\mathrm{TiO}_{2}$ were compared, and it was found that the nature of the promoter (either $\mathrm{Au}$ or $\mathrm{CuO}$ ) shifts the selectivity of the process towards two strategic products: $\mathrm{CH}_{4}$ or $\mathrm{H}_{2}$. The catalytic results were discussed in depth and correlated with the physicochemical features of the photocatalysts.
\end{abstract}

Keywords: $\mathrm{CO}_{2}$ photoreduction; reactor design; titanium dioxide; $\mathrm{CuO}$ and $\mathrm{Au}$ promotion; $\mathrm{CO}_{2}$ adsorption

\section{Introduction}

Carbon dioxide is responsible for the climate changes of the last century, and for this reason it is considered as the greatest threats to the environment of the twenty-first century [1]. The dependence of developed countries on traditional fuels has driven the research looking for sustainable and readily available energy sources [2,3]. Paris Agreement, signed in Paris in December 2015, pointed out the necessity of finding reliable technology to avoid a $2{ }^{\circ} \mathrm{C}$ global warming [4].

Carbon dioxide can be used as a green source of carbon for fuels and chemicals [5-7]; however, its exploitation is deeply connected to technological breakthroughs and the market competitiveness of these processes [8]. In this frame, photocatalysis is a promising technology, since it allows the use of $\mathrm{CO}_{2}$ to synthetize fuels in the presence of an irradiated semiconductor [9-11]. This means that the primary source of energy of the entire process is light, opening new possibilities to use solar light in the next future [12]. Water can be used as a green and sustainable reductant instead of other 
more hazardous and expensive reductants like hydrogen [13-15]. Though it has many advantages from an economic point of view, the use of water may lead also to the formation of hydrogen due to water splitting reaction [16-19]. Hydrogen might be a key molecule for the energy market in the next future [20,21]; however, its formation would not involve the use of carbon dioxide as a green source of energy $[22,23]$.

Among semiconductors, titanium dioxide has proven to be a perfect candidate for this application [24-26]. In particular, its valence band (VB) is sufficiently positive to oxidize water, while, differently from many semiconductors (like $\mathrm{WO}_{3}, \mathrm{SnO}_{2}$ and $\mathrm{Fe}_{2} \mathrm{O}_{3}$ [27]), the conduction band (CB) is negative enough for $\mathrm{CO}_{2}$ reduction [8].

Since the pioneering work by Inoue and co-workers [28], many efforts have been devoted to increase the overall efficiency of the photoreduction process, especially by focusing on both reaction media and conditions. In particular, liquid phase systems were widely tested for this reaction, though low carbon dioxide solubility and low light permeation limited the exploitation of this technology $[29,30]$. Therefore, gas phase systems were investigated in the last years [31], even if in such cases the reaction conditions needed to be pushed to convert carbon dioxide into fuels, hence decreasing the sustainability of the whole process [24].

In a previous work [16], we reported that carbon dioxide photoreduction can be performed in gas phase at room temperature and atmospheric pressure, making the process less energy demanding and more sustainable. However, some improvements need to be fulfilled in order to improve the efficiency. Crucial parameters, such as light harvesting and catalyst composition, have to be further investigated.

As a matter of fact, attention has been focused on photocatalyst modification [32-35]. Indeed, the most critical issue to be controlled and tuned is the fast electron-hole recombination at the photoexcited catalytic sites [36,37]. Anatase phase is the most suitable titania crystalline phase because of its slightly lower recombination rate, a feature highly required in this process [38-41]. Moreover, materials design, and in particular small particle size and reduced grain boundaries (such as in titanium dioxide nanotubes and nanorods) proved to be effective in exposing photocatalytic sites [42]. Crystal phase and particle structure aside, the addition of another semiconductor as a co-catalyst has been applied to limit electron-hole recombination $[7,43,44]$ and, at the same time, potentially reduce photocorrosion of semiconductors resulting from charge carrier accumulation and thus improve photocatalysts stability [45].

The differences in valence and conduction levels in the two semiconductors allow an electron flow at the heterojunction of the two species, modifying the circulation of photoexcited electrons on the final material [46]. In order to be effective in injecting electron into titania $C B$, the coupled semiconductor must be characterized by a higher Fermi level and a more negative CB $[47,48]$. Copper(II) oxide appears to be a good candidate as a co-catalyst due to its electronic properties, great availability and low cost [49]. According to Qin et al., the addition of surface copper species improves titania photoactivity by enhancing the separation of strong oxidative holes and reductive electrons [50]. Interestingly, Isahak et al. reported that $\mathrm{CuO}$ is an efficient $\mathrm{CO}_{2}$ adsorbent, favouring the interaction between substrates and the photocatalytic surface [51].

Another strategy to suppress electron-hole recombination is the introduction of noble metal nanoparticles (such as silver and gold) on the titania surface [52-55]. In these materials, the excited electrons flow from the semiconductor to the metal under light irradiation [56]. Then, the Schottky barrier at the interphase between the titanium oxide and the metal nanoparticle, hinders electron flow to titanium dioxide, preventing electron-hole recombination and thus acting as an electron trap [20,53,57-61]. Besides these electron-trapping properties, gold and silver nanoparticles are also characterized by the surface plasmonic resonance (SPR) effect [62]. Moreover, the collective oscillation of the valence electrons in semiconductors can occur under irradiation, increasing electronic propagation on the semiconductor surface [63-65]. Although all these phenomena modify the overall electronic circulation, they have a different effect on the activity and selectivity displayed by titania in the $\mathrm{CO}_{2}$ photoreduction, with consequences on the efficiency of the overall process. Actually, in order 
to make this process an efficient and sustainable technology, it is important to develop an active and selective photocatalytic process. Therefore, sustainability will be a feature not only for the catalyst, but also for the process itself. In fact, gas phase medium was chosen to maintain mild conditions (i.e., room temperature and atmospheric pressure). Catalyst efficiency was also considered and a new thin film reactor was developed to increase titania effectiveness in light harvesting and reduce the amount of catalyst.

Therefore, the goal of the work is to investigate the possibility of an efficient system for $\mathrm{CO}_{2}$ photoreduction using $\mathrm{CuO}-\mathrm{TiO}_{2}$ and $\mathrm{Au}-\mathrm{TiO}_{2}$ photocatalytic materials for a sustainable process focusing on activity and selectivity, though maintaining very mild conditions (i.e., room temperature and atmospheric pressure).

\section{Results}

\subsection{On the Reactor Design}

All reaction configurations found in the literature for a gas phase reaction were considered. In particular, in fixed bed reactors [66], which are the simplest systems, only a small fraction of the photocatalyst is activated by light, decreasing the effectiveness of the whole process. The use of honeycomb monolyths [67] and optical fibres could solve the problem, though narrowness of cells would limit the light transfer and the mass transport of reagents/products to/from the active sites. An appealing alternative is the impregnation of the photocatalyst on a moist quartz wool [68], as reported by Bazzo and Urawaka [69]. However, in this case, the amount of water in the gas phase is not controlled, leading to differences in the $\mathrm{CO}_{2} / \mathrm{H}_{2} \mathrm{O}$ ratio calculations.

Therefore, to boost the titania effectiveness in the $\mathrm{CO}_{2}$ conversion, a new thin film reactor was developed. In literature, there are some examples, which are still not optimal for light exploitation. For example, in the work by Fang and co-workers [70], the catalyst is spread as a paste onto reactor's bottom; in this way, reported reactor configuration implies light scattering through reactor and photons loss.

In this work, the photocatalyst was coated directly on the reactor surface, which is directly irradiated, thus avoiding light absorption from reaction medium, which usually happens in reported thin film reactors [46,71]. This option allowed us to reduce the amount of catalyst from $400 \mathrm{mg}$ to $10 \mathrm{mg}$ and, most importantly, to expose all the employed catalyst to incident light; in this way, the catalyst is more prone to provide the photocatalytic effect. Moreover, diffusion problems detected in previous works were avoided.

Before photocatalytic tests, blank tests were performed to avoid traces of organic species that might lead to bias in results collection and interpretation, and thus to misleading results [72]. In materials formulation, all metalorganic precursors were avoided and only inorganic salts were used; sulphates and chlorides spare ions were eliminated by washing, whilst nitrates were decomposed during calcination. However, to verify the absence of carbonaceous species possibly deriving from manipulation, several blank tests were performed without light, a catalyst, or reactants. In all of the three cases, no hydrocarbons were detected in reaction mixture. In addition to that, a test with catalyst, light, and water (so without $\mathrm{CO}_{2}$ only) was performed and no C-based product was detected, confirming the absence of carbonaceous species on the surface. From these evidences, it is established that this is not a photochemical process, but a photocatalytic reaction. Moreover, catalysts are C-free and photostable, proving catalyst results significance.

In Figure 1, the comparison between the photoactivity obtained either with the fixed bed reactor or with the thin film reactor is reported. For these tests, a commercial titanium dioxide materials was used as a benchmark catalyst. It is clear that methane formation increases enormously (from $0.03 \mu \mathrm{mol} \mathrm{g} \mathrm{cat}^{-1}$ to $14.00 \mu \mathrm{mol} \mathrm{g}_{\mathrm{cat}}{ }^{-1}$ ) when using a thin film reactor; this means that there are three orders of magnitude of difference between the photocatalytic performances of the same catalyst in the same experimental conditions, but in the presence of the two different photocatalytic setups. Obtained data are in line with 
those generally reported in literature, if not higher. However, a quantitative comparison with literature data is very challenging, since it is affected by differences in reaction conditions (such as phase, temperature, pressure, irradiance, reagents ratio, catalysts, etcetera) leading to misinterpretations. For example, Camarillo et al. recently reported a methane formation of $0.172 \mu \mathrm{mol} \mathrm{g} \mathrm{cat}^{-1} \mathrm{~h}^{-1}$ using a $\mathrm{Pt} / \mathrm{TiO}_{2}$ catalyst $[73,74]$, while Tan and co-workers reported a miximum $3.14 \mu \mathrm{mol} \mathrm{g}_{\mathrm{cat}}{ }^{-1}$ after eight hour reactions with graphene oxide-modified $\mathrm{TiO}_{2}$ [75], and Ola and Maroto-Valer reached $4.87 \mu \mathrm{mol}$ $\mathrm{g}_{\mathrm{cat}}{ }^{-1}$ by means of a $\mathrm{V}-\mathrm{TiO}_{2}$ photocatalyst [76].

Compared to cited works, reaction conditions here are considerably milder, particularly in terms of irradiance; in fact, they are in cited paper irradiance ranges from 500 to $3000 \mathrm{~W} \cdot \mathrm{m}^{-2}$, whilst here irradiance is $50 \mathrm{~W} \cdot \mathrm{m}^{-2}$. Therefore it is possible to obtain similar results minimising the primary energy input.

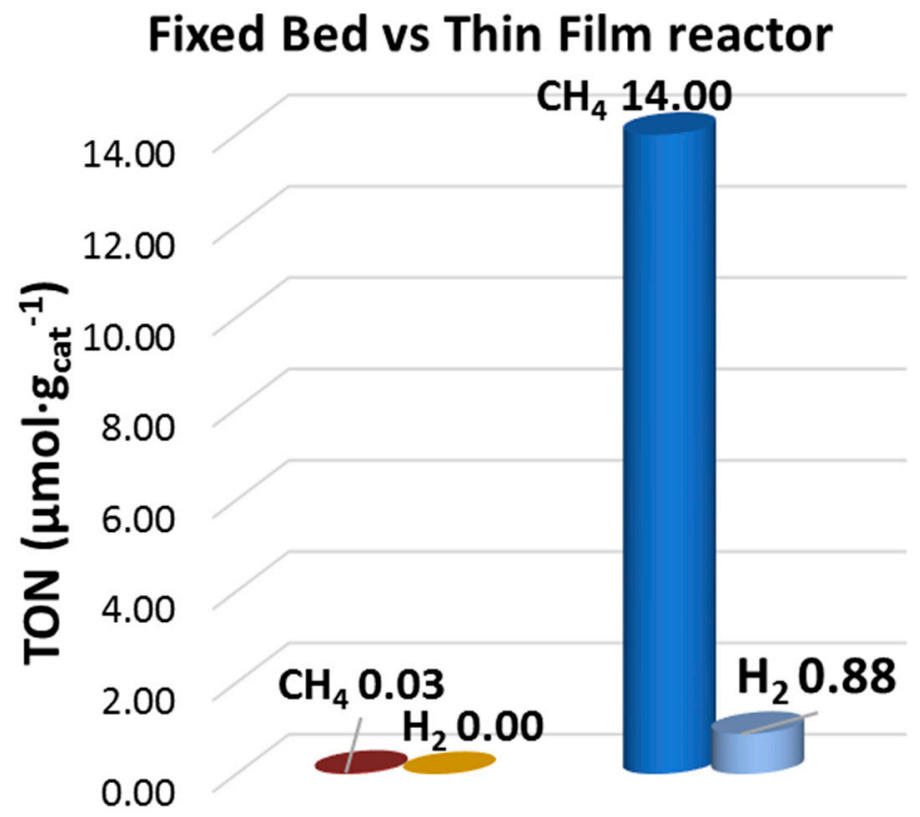

Figure 1. Benchmark titania photocatalytic activity in fixed bed and thin film reactors.

Reported photocatalytic tests were performed in static conditions and for a relatively long time (6 h); therefore, it can be easily supposed that, in this case, thermodynamically favoured products are more likely to be formed than kinetic-favoured ones. As a matter of fact, methane formation, which, on one hand, requires the highest amount of photoexcited electrons, is, on the other hand, the most probable event compared to the conversion to $\mathrm{CO}, \mathrm{HCHO}$, and methanol. Oxygen is always observed as a co-product, but its productivity is not reported, since it is affected by retention in oxygen vacancies within titania lattice [77].

It is worth noting that this result cannot be ascribed to the different amount of catalyst employed for each test. Indeed, the small amount of catalyst and the use of a thin film promote the adsorption of reagents on the active sites, as well as the product desorption. These steps need to be as fast as possible to make catalytic sites available for new carbon dioxide molecules to adsorb again. This means that within the thin film reactor the mass transport is facilitated compared to the fixed bed reactor, hence making products desorption easier and, as a consequence, their subsequent collection as well. To sustain this statement, light harvesting is more efficient on thin film deposited catalyst; as a matter of fact, in this case quantum yield is $0.11 \%$ to $2.31 \times 10^{-4 \%}$.

Finally, the photoactivity was so low when using the fixed bed reactor that no other product was observed. On the contrary, the increased photoefficiency in the case of the thin film reactor would allow 
to observe any other products, namely hydrogen. Such a molecule comes from the water splitting, that is, a side reaction that might occur under the same experimental conditions.

\subsection{Characterisation of the Unpromoted $\mathrm{TiO}_{2}$ Photocatalyst}

Preliminary to the investigation on the effect of the dopants, the morphological properties and photocatalytic activity of the unpromoted titania sample were studied.

In order to obtain efficient photocatalysts, the titania crystalline phase is an important parameter and anatase phase is highly suitable [78]. Aimed at finding the optimal calcination temperature to obtain $\mathrm{TiO}_{2}$ in the anatase form, TG/DTA analysis was performed on the uncalcined sample. The results are reported in Figure 2.

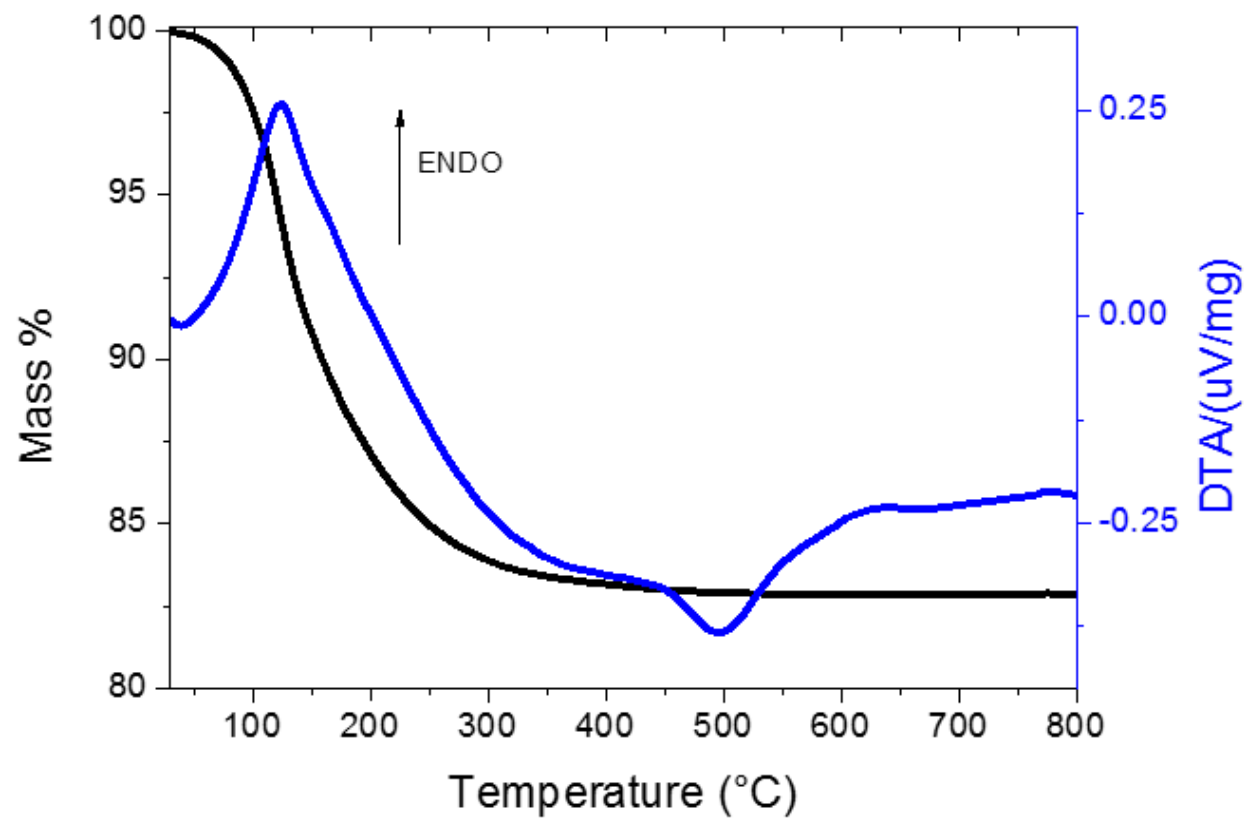

Figure 2. Uncalcined titania TG/DTA analysis.

According to the TG curve, the weight loss takes place in a single stage from $60{ }^{\circ} \mathrm{C}$ to $400{ }^{\circ} \mathrm{C}$. The endothermic peak centred at $120^{\circ} \mathrm{C}$ can be attributed to the loss of water. Moreover, an exothermic process without any weight loss is observed between $400{ }^{\circ} \mathrm{C}$ and $600{ }^{\circ} \mathrm{C}$. In agreement with literature data [79], this process can be ascribed to the phase transition from amorphous to crystalline titania in the anatase phase. In addition to that, from TG/DTA analysis, no other process exists due to impurities degradation. In fact, only inorganic salts were used in samples preparation, and sulphate spare ions were eliminated completely.

Considering the TG/DTA results, it was proposed that the calcination at $400{ }^{\circ} \mathrm{C}$ could be an optimal compromise to retain relative high surface area of titania and, at the same time, to assure the transition from amorphous titania to crystalline anatase phase.

The calcined unpromoted titania sample was then tested in the $\mathrm{CO}_{2}$ photoreduction. The results are reported in Figure 3, in which the comparison with those obtained for the commercial titania reference is shown. 


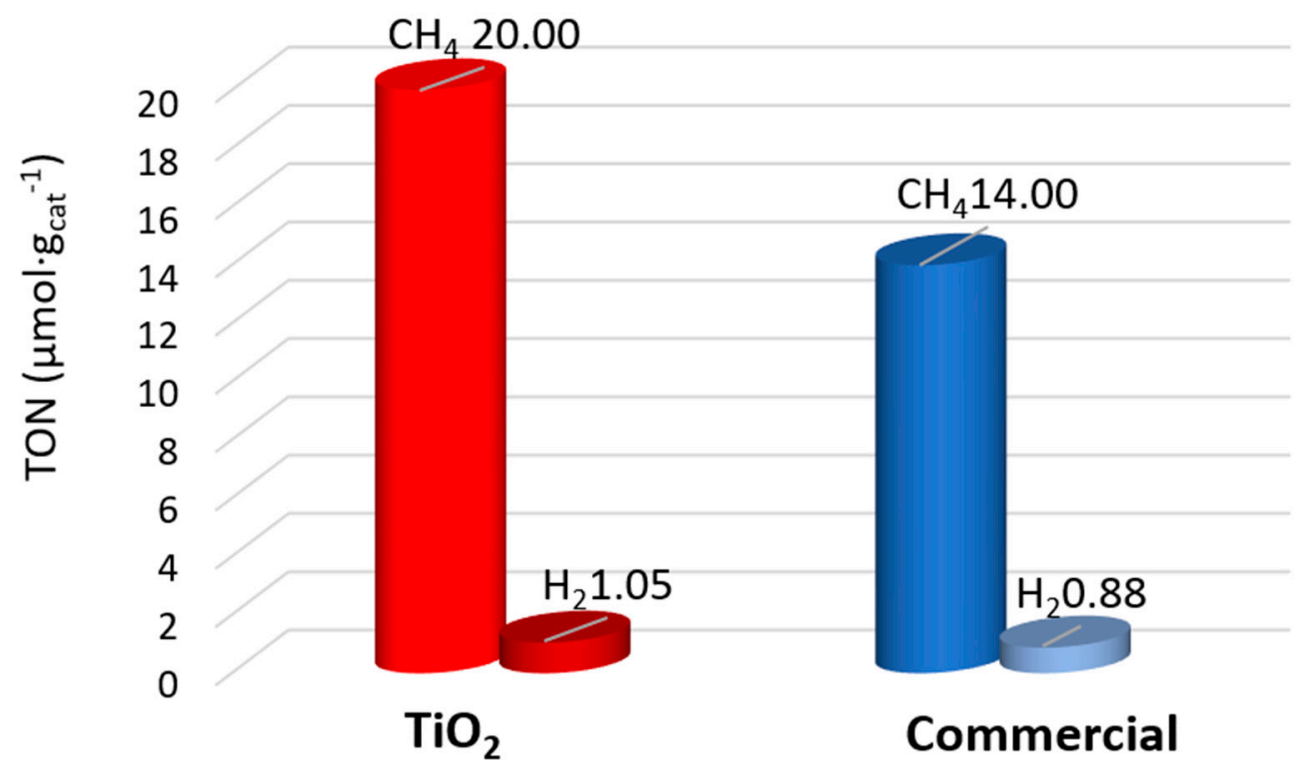

Figure 3. Photoactivity tests in the $\mathrm{CO}_{2}$ photoreduction performed on unpromoted $\mathrm{TiO}_{2}$ (red columns) and commercial titania (blue columns).

First of all, it was observed that in the presence of both catalysts the only detected products are methane and hydrogen; the former derives from the $\mathrm{CO}_{2}$ photoreduction and the latter comes from the water splitting. Moreover, the product distribution is definitely shifted towards methane; as a matter of fact, selectivity to methane is $95 \%$ for both samples. This can be explained by remembering proposed reaction mechanism in gas phase in similar conditions [80]; by combining experimental data with spectroscopic evidences from literature, it was hypothesised that fast deoxygenation drives selectivity towards methane, thus avoiding the production of oxygentated compounds. However, in literature several reaction mechanisms for methane and oxygen formation from carbon dioxide and water are reported, which means that stoichiometry for this process has not been unanimously established yet and non-stoichiometric reaction cannot be excluded.

Interestingly, the unpromoted titania sample provides a considerably higher productivity towards methane than the commercial titania $\left(20.00 \mu \mathrm{mol}_{\mathrm{CH} 4} \cdot \mathrm{g}_{\mathrm{cat}}{ }^{-1}\right.$ by $\mathrm{TiO}_{2}$ sample vs. $14.00 \mu \mathrm{mol}_{\mathrm{CH} 4} \cdot \mathrm{g}_{\mathrm{cat}}{ }^{-1}$ by reference material), whereas the difference in hydrogen productivity is small $\left(1.05 \mu \mathrm{mol}_{\mathrm{H} 2} \cdot \mathrm{g}_{\mathrm{cat}}{ }^{-1}\right.$ by $\mathrm{TiO}_{2}$ sample vs. $0.88 \mu \mathrm{mol}_{\mathrm{H} 2} \cdot \mathrm{g}_{\text {cat }}{ }^{-1}$ by reference material).

Both methane and hydrogen yields are comparable to, if not higher than, those found in the literature, though the reaction conditions adopted within this study are considerably milder. In particular, either carbon dioxide pressure or irradiance is considerably lower than those reported in most of literature, in which the photon energetic input was extremely high $[9,81,82]$.

Therefore, in order to understand the different behaviours observed in the reactivity tests and to establish structure-activity relationships, a deep physicochemical characterisation was performed.

The first investigated parameters were the specific surface area and the pore volume, crucial features for every heterogeneous catalyst [41]. The surface properties have been examined by means of nitrogen physisorption, and the obtained absorption/desorption isotherms are reported in Figure 4 . 


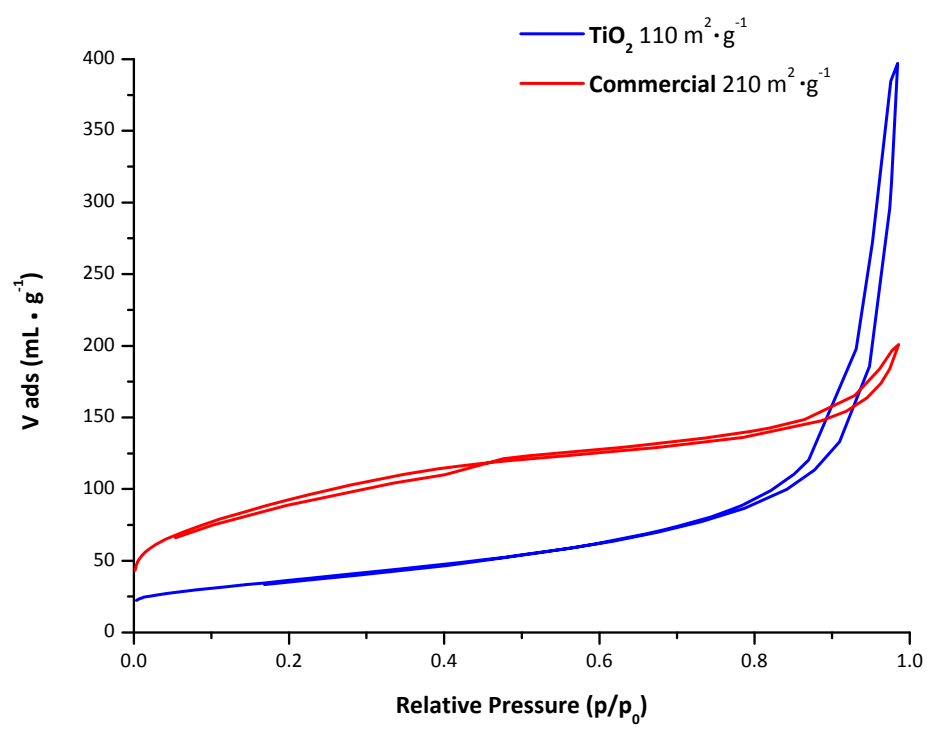

Figure 4. $\mathrm{N}_{2}$ physisorption isotherms of unpromoted $\mathrm{TiO}_{2}$ (red curves) and commercial titania (blue curves).

The unpromoted $\mathrm{TiO}_{2}$ sample shows a type IV isotherm typical of mesoporous materials. The hysteresis loop is shifted towards high relative pressures (between 0.8 and $1 \mathrm{p} / \mathrm{p}_{0}$ ), indicating a narrow distribution of pores that is centred on $25 \mathrm{~nm}$. The isotherm curves related to commercial titania are different, since they are characterized by a higher nitrogen adsorption at low relative pressures and a wider hysteresis loop, corresponding to a wider and non-homogeneous pore size distribution if compared to unpromoted $\mathrm{TiO}_{2}$. Moreover, the commercial sample provides a higher surface area $\left(217 \mathrm{~m}^{2} \cdot \mathrm{g}^{-1}\right)$ than the synthesised sample $\left(110 \mathrm{~m}^{2} \cdot \mathrm{g}^{-1}\right)$. The comparison between the obtained specific surface areas and the photoactivity indicated that the commercial sample, despite possessing the highest surface area, shows the lowest photocatalytic activity. These findings suggested that a high surface area is not a crucial parameter in the adopted reaction conditions.

Then, both crystallinity and crystal phase of the examined samples were studied by XRD analysis. The results are shown in Figure 5.

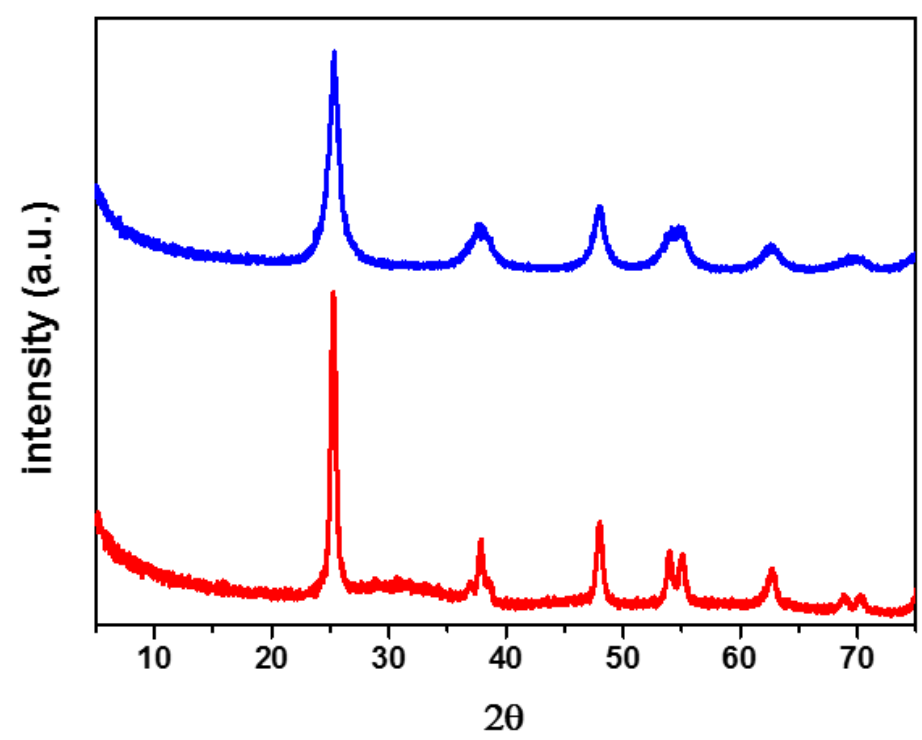

Figure 5. XRD patterns of unpromoted $\mathrm{TiO}_{2}$ (red curve) and commercial sample (blue curve). 
In both cases, the observed crystalline phase was anatase, i.e., the most suitable phase for photocatalytic purposes, as previously discussed [38]. The diffraction peaks related to the commercial sample are wider and less defined than those of the unpromoted $\mathrm{TiO}_{2}$ photocatalyst. Such feature is an indication that the commercial sample is made of titania nanoparticles smaller than those present in the $\mathrm{TiO}_{2}$ sample, in agreement with the $\mathrm{N}_{2}$ physisorption measurements which provided a surface area $\left(217 \mathrm{~m}^{2} \cdot \mathrm{g}^{-1}\right)$ for the commercial sample higher than that of the synthesised $\mathrm{TiO}_{2}$ sample $\left(110 \mathrm{~m}^{2} \cdot \mathrm{g}^{-1}\right)$.

In addition, the different width and magnitude of the XRD peaks could also point out that a large fraction of the commercial sample is mainly made up of amorphous titania, and that present anatase crystals are smaller in size compared to lab-made $\mathrm{TiO}_{2}$. Indeed, the commercial titania purchaser stated that only $40 \mathrm{wt}$. \% of the reference material is crystalline and in the anatase phase, whilst it was found that in the unpromoted $\mathrm{TiO}_{2}$ the anatase phase is more than $95 \mathrm{wt}$. \% of the sample and only a small fraction is amorphous. Therefore, the XRD evidences, along with the catalytic results (showed in Figure 3), suggest that the sample crystallinity affects the $\mathrm{CO}_{2}$ photoreduction activity, whereas it has no influence on the selectivity.

\subsection{Effect of the Promoters on the Properties and Activity of the $\mathrm{TiO}_{2}$ Photocatalysts}

In order to further improve the effectiveness of the titania photocatalyst, two different promoters, i.e., $\mathrm{CuO}$ and $\mathrm{Au}$, were introduced into the $\mathrm{TiO}_{2}$ sample. In particular, the same amount $(0.2 \mathrm{wt}$. \% on metal base) of promoter was added, as confirmed by the FAAS analysis. Due to such low amount, the promoters were not detected by XRD analysis, and it was found that the addition of the promoter has a negligible effect on the specific surface area, as demonstrated by $\mathrm{N}_{2}$ physisorption results reported in Table 1.

Table 1. Specific Surface Areas of the examined photocatalysts obtained by $\mathrm{N}_{2}$ physisorption analyses.

\begin{tabular}{cc}
\hline Photocatalyst & BET Specific Surface Area $\left(\mathbf{m}^{2} / \mathbf{g}\right)$ \\
\hline MIRKAT 211 & 217 \\
$\mathrm{TiO}_{2}$ & 110 \\
$\mathrm{CuO}-\mathrm{TiO}_{2}$ & 100 \\
$\mathrm{Au}-\mathrm{TiO}_{2}$ & 100 \\
\hline
\end{tabular}

The nature of the promoters was then investigated, and TPR analyses were resorted to in order to have information on the oxidation state of copper and gold after insertion into the $\mathrm{TiO}_{2}$ sample.

TPR measurements revealed that copper is present as $\mathrm{Cu}(\mathrm{II})$, due to a single hydrogen consumption at $180^{\circ} \mathrm{C}$ ascribable to $\mathrm{Cu}$ (II) reduction to $\mathrm{Cu}(0)$ (Figure 6, green curve), whereas gold is in its ground state, since no hydrogen consumption was observed (violet curve in the same figure).

The diffuse reflectance UV-Vis-NIR spectra of the $\mathrm{CuO}-\mathrm{TiO}_{2}$ (green curve) and $\mathrm{Au}-\mathrm{TiO}_{2}$ (violet curve) photocatalysts are shown in Figure 7. 


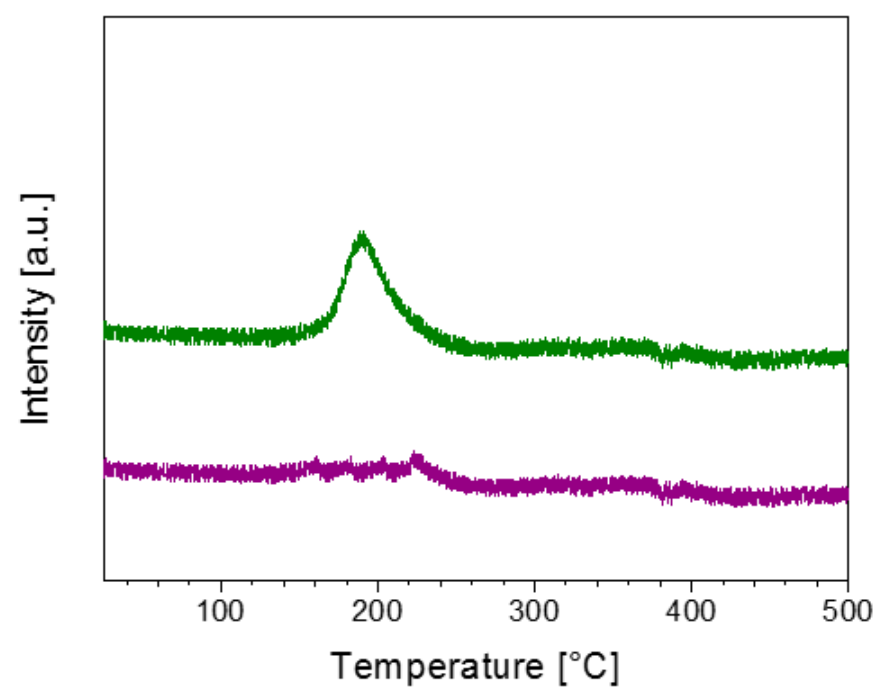

Figure 6. TPR analyses of $\mathrm{CuO}-\mathrm{TiO}_{2}$ sample (green curve) and $\mathrm{Au}-\mathrm{TiO}_{2}$ sample (violet curve).

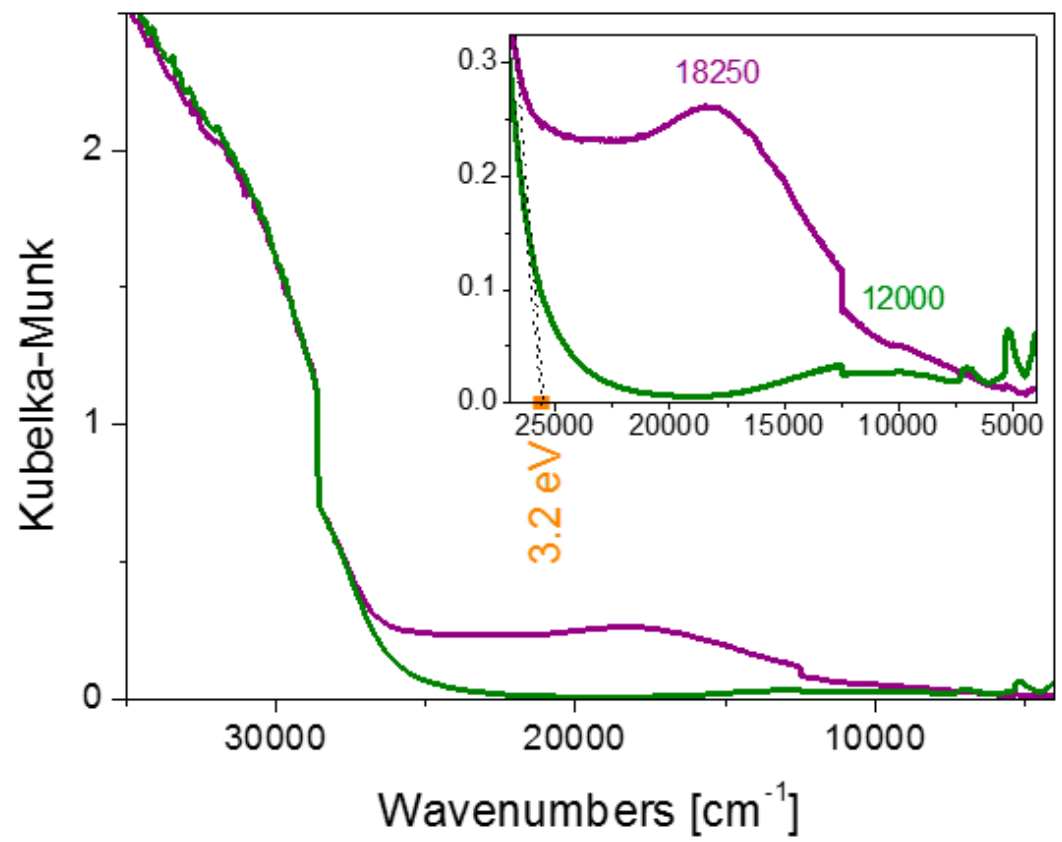

Figure 7. Diffuse reflectance UV-Vis-NIR spectra of the $\mathrm{CuO}-\mathrm{TiO}_{2}$ (green curve) and $\mathrm{Au}-\mathrm{TiO}_{2}$ (violet curve) photocatalysts. Inset: zoom of the spectra in the Vis-NIR region.

The presence of the promoters does not seem to modify the titania electronic properties, since the absorption in the UV region was comparable, and no significant modification in the band gap value was observed; a value corresponding to $3.2 \mathrm{eV}$ (orange point in the inset of Figure 7), which is the typical value for titania in the anatase form, was obtained in both cases. On the contrary, some differences were observed in the Vis-NIR region, as shown in the inset of Figure 7. In particular, a broad absorption centred at $18,250 \mathrm{~cm}^{-1}$, and due to the plasmonic resonance of gold nanoparticles $[83,84]$, was observed for the $\mathrm{Au}-\mathrm{TiO}_{2}$ sample. Differently, a weak absorption centred at $12,000 \mathrm{~cm}^{-1}$, assigned to d-d transition in $\mathrm{Cu}$ (II) species, was detected and ascribed to the presence of copper oxide nanoparticles $[85,86]$ on the $\mathrm{CuO}-\mathrm{TiO}_{2}$ photocatalyst. Even if the presence of the promoters did not affect the titania band gap value, the presence of such species is aimed at reducing the electron-hole recombination by modifying the interaction between the titania surface and light. 
After having considered the chemical nature of the promoters, the $\mathrm{Au}-\mathrm{TiO}_{2}$ and the $\mathrm{CuO}-\mathrm{TiO}_{2}$ samples were tested in the $\mathrm{CO}_{2}$ photoreduction. The results are reported in Figure 8 with those already obtained for the unpromoted $\mathrm{TiO}_{2}$ sample.

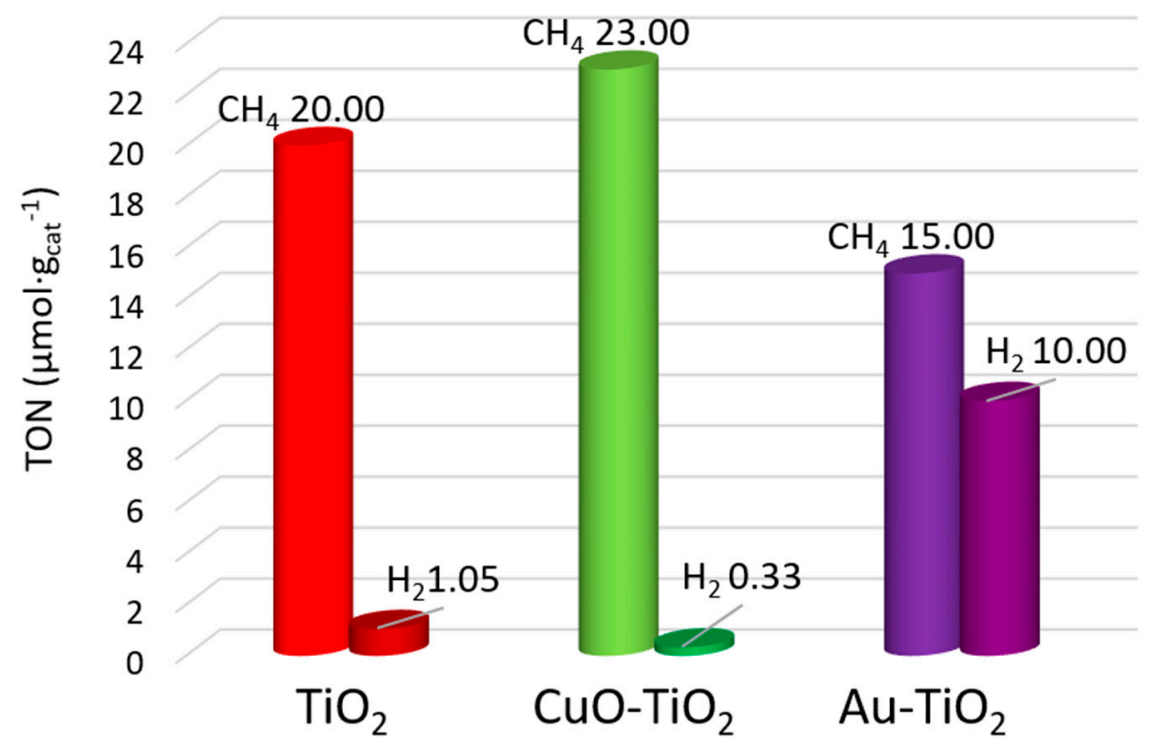

Figure 8. Photoactivity tests in the $\mathrm{CO}_{2}$ photoreduction performed on unpromoted $\mathrm{TiO}_{2}$ (red columns), CuO- $-\mathrm{TiO}_{2}$ (green columns), and $\mathrm{Au}-\mathrm{TiO}_{2}$ (violet columns) catalysts.

As previously observed for the $\mathrm{TiO}_{2}$ photocatalysts (Figure 3), the selectivity as for the nature of the formed species did not vary upon the promoter insertion, since the detected products were methane and hydrogen also in this case. However, the presence of $\mathrm{CuO}$ and $\mathrm{Au}$ promoters influenced the activity, as well as the selectivity, in the $\mathrm{CO}_{2}$ photoreduction. In particular, if compared to the undoped sample, the promotion by $\mathrm{CuO}$ slightly increased the catalyst photoactivity toward the formation of methane (from 20.00 to $23.00 \mu \mathrm{mol}_{\mathrm{CH} 4} \cdot \mathrm{g}_{\mathrm{cat}}{ }^{-1}$ ) and, at the same time, it suppressed the hydrogen production by water splitting. Indeed, the selectivity to methane increased from $95 \%$ for the undoped $\mathrm{TiO}_{2}$ sample to $98 \%$ for the $\mathrm{CuO}-\mathrm{TiO}_{2}$ sample. Differently, the sample containing $\mathrm{Au}$ nanoparticles gave the lowest methane production $\left(15.00 \mu \mathrm{mol}_{\mathrm{CH} 4} \cdot \mathrm{g}_{\mathrm{cat}}{ }^{-1}\right)$, whereas the production of hydrogen was considerably higher $\left(10.00 \mu \mathrm{mol}_{\mathrm{H} 2} \cdot \mathrm{g}_{\mathrm{cat}}{ }^{-1}\right)$, leading to a $60 \%$ selectivity to methane. Considering light harvesting for $\mathrm{CO}_{2}$ photoreduction, copper introduction increases quantum yield from $4.75 \times 10^{-4 \%}$ for the undoped sample to $5.48 \times 10^{-4 \%}$ for $\mathrm{CuO}^{-\mathrm{TiO}_{2}}$ sample, whilst it decreases to $3.56 \times 10^{-4} \%$ for $\mathrm{Au}-\mathrm{TiO}_{2}$ sample.

The above results demonstrated that the introduction of $\mathrm{CuO}$ on the $\mathrm{TiO}_{2}$ catalyst favoured the $\mathrm{CO}_{2}$ photoreduction and, on the contrary, the presence of Au nanoparticles increased the activity in the water splitting reaction. It must be considered that the reaction takes place only if the interaction between carbon dioxide and water occurs at the photoexcited catalytic surface [23]. Therefore, if only water is adsorbed at the surface, only water splitting reaction happens, since the $\mathrm{CO}_{2}$ molecule is more difficultly adsorbed than water on the surface of titania [87]. To overcome this issue, the reaction has been performed in the presence of large excess of $\mathrm{CO}_{2}\left(\mathrm{CO}_{2} / \mathrm{H}_{2} \mathrm{O}\right.$ molar ratio was 13.3), even though the water splitting reaction was not completely suppressed. The catalytic data indicate that the introduction of gold nanoparticles on the $\mathrm{TiO}_{2}$ surface seems to increase the hydrophilicity of the photocatalyst and, as a consequence, the capability of $\mathrm{Au}-\mathrm{TiO}_{2}$ to adsorb $\mathrm{CO}_{2}$ was diminished. Carneiro et al. reported that gold nanoparticles are able to modify hydroxyl group's population on titania [88]. Hence, it can be proposed that the different surface properties of $\mathrm{CuO}-\mathrm{TiO}_{2}$ and $\mathrm{Au}-\mathrm{TiO}_{2}$ play a key role in the reaction, as revealed by the different photocatalytic behaviour displayed by the two photocatalysts. 


\subsection{Influence of the Surface and Electronic Properties on the Photoactivity of $\mathrm{CuO}-\mathrm{TiO}_{2}$ and $\mathrm{Au}-\mathrm{TiO}_{2}$}

In order to explain the different behaviour displayed by the two promoted catalysts during the $\mathrm{CO}_{2}$ photoreduction, FTIR measurement were performed on both $\mathrm{CuO}-\mathrm{TiO}_{2}$ and $\mathrm{Au}-\mathrm{TiO}_{2}$ samples.

The FTIR absorbance spectra collected on $\mathrm{CuO}-\mathrm{TiO}_{2}$ and $\mathrm{Au}-\mathrm{TiO}_{2}$ samples upon outgassing from r.t. up to $150{ }^{\circ} \mathrm{C}$ are reported in Figure 9. As specified in the experimental section, the spectra have been normalised to the density of the pellets. Therefore, the intensity of the absorption bands can be taken as a measure of the amount of adsorbed species and of their stability to the outgassing at increasing temperature on the two photocatalysts. The intense absorption centred at about $3400 \mathrm{~cm}^{-1}$ and the peak at $1632-1629 \mathrm{~cm}^{-1}$ observed on both $\mathrm{CuO}-\mathrm{TiO}_{2}$ and $\mathrm{Au}-\mathrm{TiO}_{2}$ are due to the stretching and bending modes, respectively, of $\mathrm{OH}$ groups related to the presence of adsorbed molecular water (navy curves). The largest fraction of such molecules is easily removed upon degassing the samples at r.t. for $30 \mathrm{~min}$ (bold blue curves); however, a monolayer of hydroxyl groups and water molecules is still present [89] and gradually decreases upon outgassing at increasing temperature, up to $150{ }^{\circ} \mathrm{C}$ (red curves), as confirmed by the peak at $3673(3671) \mathrm{cm}^{-1}$ with a weak shoulder at $3721(3718) \mathrm{cm}^{-1}$, due to the stretching mode of two types of free hydroxyl groups $[90,91]$ (see the insets in Figure 9). These features give an idea of the behaviour of the catalyst at the surface during the $\mathrm{CO}_{2}$ photoreduction, which is performed at room temperature in the presence of water. However, if compared with $\mathrm{CuO}-\mathrm{TiO}_{2}$, the $\mathrm{Au}-\mathrm{TiO}_{2}$ photocatalyst possesses a more hydrophilic surface, since the intensity of the bands due to the presence of adsorbed water molecules is much higher than those related to carbonate species and observed at lower frequencies $\left(v<1600 \mathrm{~cm}^{-1}\right)$ that will be discussed in detail afterwards.

In addition, a careful comparison among the spectra obtained on the two photocatalysts reveals, interestingly, that at frequencies lower than $2500 \mathrm{~cm}^{-1}$, the addition of gold produced a modification in the spectra, ascribed to the erosion of an electronic absorption, and occurring at all the temperatures here considered (violet curves vs. green curves in Figure 10). It is worth noting that the appearance of an electronic absorption is related to the presence of free electrons in the titania CB; its erosion is the consequence of the population of new energetic levels created when gold nanoparticles are introduced. In this case, the Schottky barrier between the metal nanoparticles and the oxide hinders electron flow to $\mathrm{TiO}_{2}$, effectively behaving as an electron trap. This phenomenon is more pronounced in the case of $\mathrm{Au}-\mathrm{TiO}_{2}$ (violet curves) than in the case of $\mathrm{CuO}-\mathrm{TiO}_{2}$ (green curves), and it is also in agreement with the DRUV-Vis results that point out a small difference in the titania band gap of the two samples (see Figure 7, inset).

Therefore, the above findings indicate that in the case of the gold-doped titania photocatalyst, a less negative potential for titania $\mathrm{CB}$ can be hypothesised, resulting in a less effective $\mathrm{CO}_{2}$ reduction [8]. Indeed, gold insertion modified the electronic circulation, but it has a detrimental effect on the activity and selectivity displayed by titania in the $\mathrm{CO}_{2}$ photoreduction if compared to $\mathrm{CuO}$-promoted titania. 


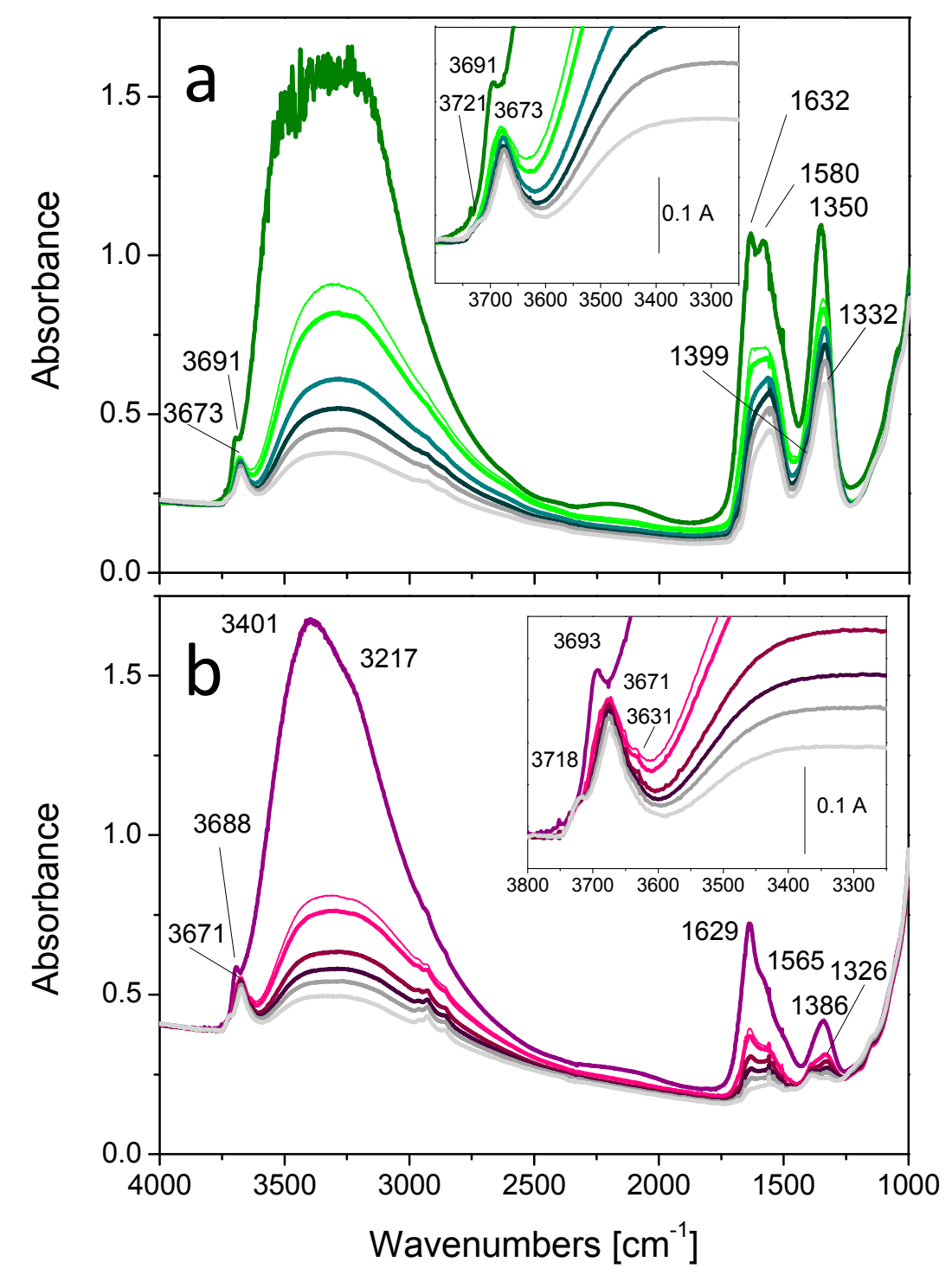

Figure 9. FTIR absorbance spectra of $\mathrm{CuO}-\mathrm{TiO}_{2}$ (a) and $\mathrm{Au}-\mathrm{TiO}_{2}$ (b) in air (olive/purple curves), under $10 \mathrm{~min}$ (fine green/pink curves) and $30 \mathrm{~min}$ (bold green/pink curves) outgassing at r.t., at $80^{\circ} \mathrm{C}$ (cyan/wine curves), at $100{ }^{\circ} \mathrm{C}$ (dark cyan/wine curves), at $120^{\circ} \mathrm{C}$ (dark grey curves), and at $150{ }^{\circ} \mathrm{C}$ (light grey curves). 


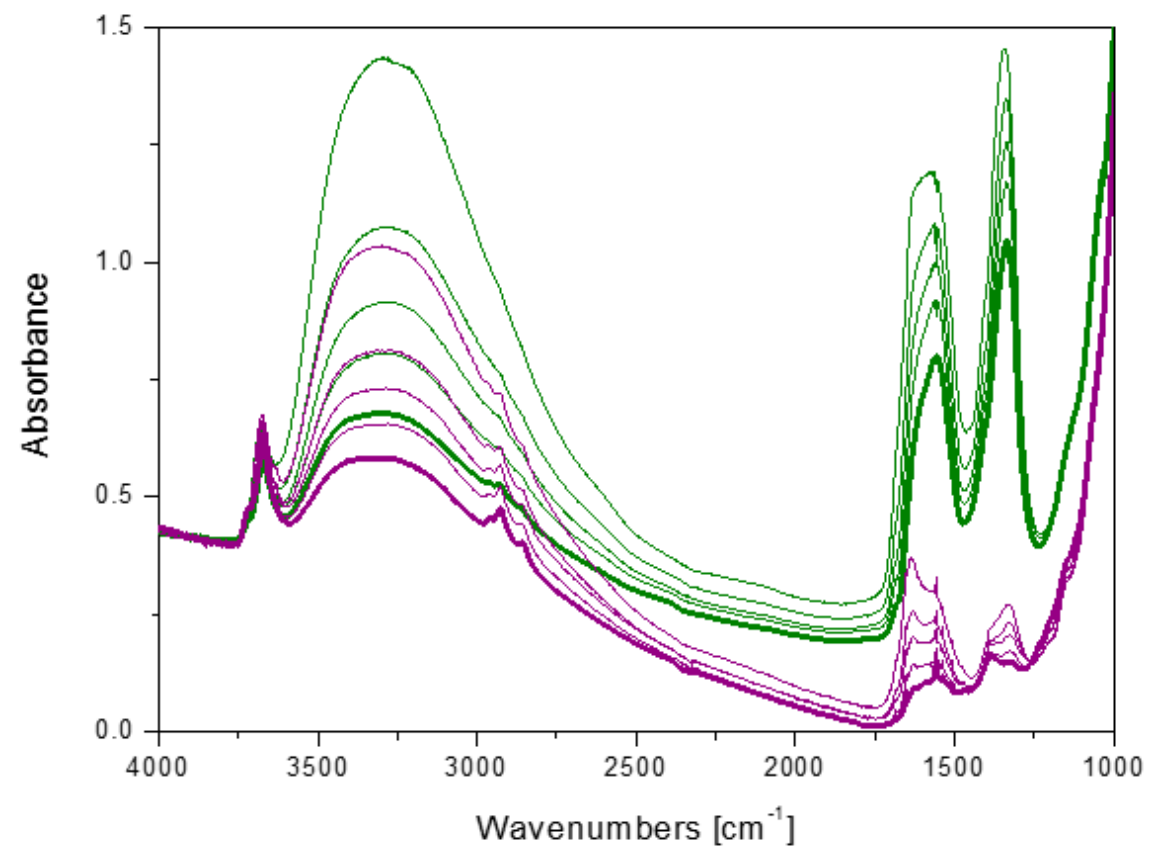

Figure 10. Comparison among the normalised FTIR absorbance spectra of $\mathrm{CuO}-\mathrm{TiO}_{2}$ (green curves) and $\mathrm{Au}-\mathrm{TiO}_{2}$ (violet curves) reported in Figure 8. Spectra normalised to the pellet density.

\subsection{Interaction with $\mathrm{CO}_{2}$ at Room Temperature: Surface Reactivity}

The adsorption of $\mathrm{CO}_{2}$ at r.t. was carried out on both samples with the aim of investigating the interaction between the reactant and the catalytic surfaces; the results are reported in Figure 11a. Before the analyses, the samples were simply outgassed from r.t. up to $150{ }^{\circ} \mathrm{C}$ for $10 \mathrm{~min}$, and then the temperature was decreased again to r.t. under outgassing. This procedure guaranteed to remove the large fraction of water molecules adsorbed at the surface, leaving only some residual of hydroxyl groups and adsorbed water molecules, as shown in Figure 11a. In addition, a number of bands are produced on the $\mathrm{CuO}-\mathrm{TiO}_{2}$ (green curves) and $\mathrm{Au}-\mathrm{TiO}_{2}$ (violet curves) photocatalysts in the $2400-2250 \mathrm{~cm}^{-1}$ and $1800-1000 \mathrm{~cm}^{-1}$ ranges (highlighted by dashed frames and enlarged in sections $\mathrm{b}$ and c, respectively) upon the inlet of 15 mbar $\mathrm{CO}_{2}$ at room temperature (bold curves).

A quite asymmetric absorption with two components at 2345 and $2352 \mathrm{~cm}^{-1}$, with a broad shoulder at about $2360 \mathrm{~cm}^{-1}$, due to carbon dioxide molecules linearly adsorbed on $\mathrm{Ti}^{4+}$ sites, is observed (Figure 11b, bold curves), and it is gradually depleted when decreasing the $\mathrm{CO}_{2}$ pressure and after outgassing at r.t. (fine curves). The intensity of the absorption observed in the case of $\mathrm{CuO}-\mathrm{TiO}_{2}$ (green curves) is higher than that related to $\mathrm{Au}-\mathrm{TiO}_{2}$, pointing out a larger amount of linearly adsorbed $\mathrm{CO}_{2}$ formed on $\mathrm{CuO}$-doped titania. Moreover, the shift of the $\Sigma_{\mathrm{u}}{ }^{+}$band of adsorbed $\mathrm{CO}_{2}$ molecules with respect to the gas phase $\left(2343 \mathrm{~cm}^{-1}\right)$ increases with the Lewis acid strength of the cationic sites [92]. Therefore, the presence of two defined peaks indicates that the $\mathrm{CO}_{2}$ molecules are adsorbed on surface $\mathrm{Ti}^{4+}$ ions with different Lewis acid strength. At the same time, bands due to carbonate-like species produced by the reaction of linearly adsorbed $\mathrm{CO}_{2}$ with $\mathrm{O}_{2}{ }^{-}$basic sites are produced (Figure 11c, bold curves) on both samples with different relative intensity. The production of carbonate-like species points out the presence of surface $\mathrm{Ti}^{4+}-\mathrm{O}^{2-}$ couples in which the basic $\mathrm{O}$ atom is able to react with the $\mathrm{C}$ atom from $\mathrm{CO}_{2}$. Carbon dioxide bent form is more destabilised than the linearly adsorbed $\mathrm{CO}_{2}$ molecule, thus providing higher reactivity in $\mathrm{CO}_{2}$ photoreduction [48]. More in detail, bands at 1641,1307 , and $1032 \mathrm{~cm}^{-1}$, and at 1572, 1366, and about $1045 \mathrm{~cm}^{-1}$, are observed. These absorptions are assigned to two different (chelate and/or bridged) bidentate carbonate species [93]. From these findings, it can be inferred that several kind of sites, i.e., those able to coordinate molecular $\mathrm{CO}_{2}$ and those producing bidentate carbonate species are present on the titania surface. All these sites are 
more abundant on $\mathrm{CuO}-\mathrm{TiO}_{2}$ than on $\mathrm{Au}-\mathrm{TiO}_{2}$. Moreover, on the $\mathrm{CuO}-\mathrm{TiO}_{2}$ catalyst, the produced species are slightly more stable to the outgassing at r.t. than on $\mathrm{Au}-\mathrm{TiO}_{2}$, as revealed by the comparison between the initial intensity (bold curves) and final intensity (fine curves) of the bands related to each sample.

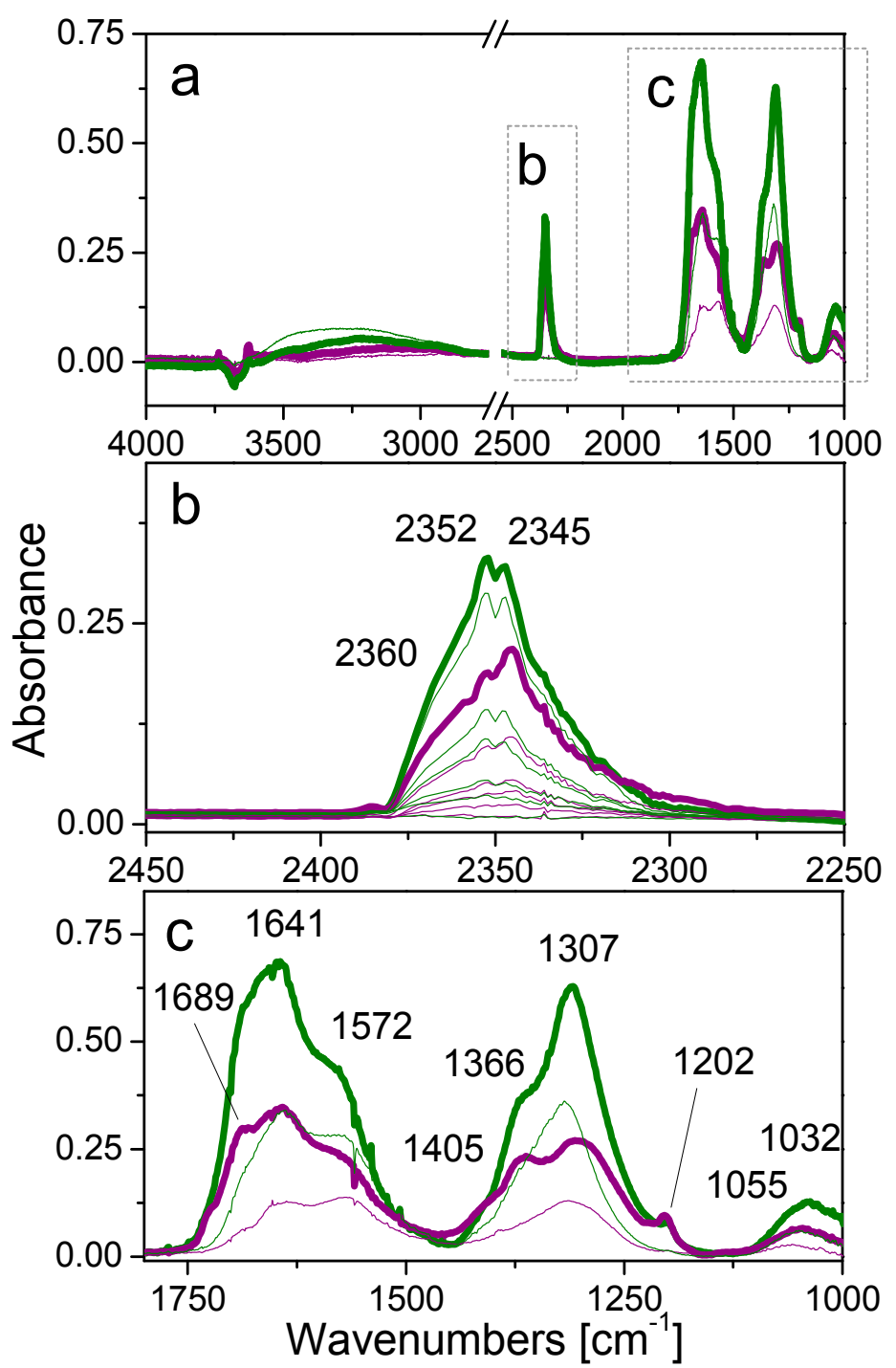

Figure 11. (a) FTIR difference spectra collected on $\mathrm{CuO}-\mathrm{TiO}_{2}$ (green curves) and $\mathrm{Au}-\mathrm{TiO}_{2}$ (violet curves) after the inlet of $15 \mathrm{mbar} \mathrm{CO}_{2}$ at r.t. (bold curves) and subsequent outgassing at the same temperature for $30 \mathrm{~min}$ (fine curves). (b) Zoom on the $2450-2250 \mathrm{~cm}^{-1}$ spectral range in which the spectra collected at decreasing $\mathrm{CO}_{2}$ pressure and under outgassing at r.t. (fine curves). (c) Zoom on the $1800-1000 \mathrm{~cm}^{-1}$ spectral range.

Finally, bands at 1689,1405 , and $1202 \mathrm{~cm}^{-1}$, with almost the same intensity for both samples, due to bicarbonate species produced by reaction of $\mathrm{CO}_{2}$ with some basic $-\mathrm{OH}$ groups, are observed $[80,94]$. A component at about $1730 \mathrm{~cm}^{-1}$, more evident in the case of $\mathrm{Au}-\mathrm{TiO}_{2}$ and tentatively assigned to carboxylate species, is also detected [95].

FTIR spectra of adsorbed $\mathrm{CO}_{2}$ definitely showed that the surface of the $\mathrm{CuO}-\mathrm{TiO}_{2}$ photocatalyst is more efficient at absorbing and reacting to the molecule, resulting in a more valuable interaction between the $\mathrm{CO}_{2}$ molecules and the photocatalytic surface [49], which represents the first step of carbon dioxide photoreduction. 
From all the experimental findings, it is possible to state that surface properties affect reactants' adsorption (particularly for $\mathrm{CO}_{2}$, the least adsorbable reactant) and, as a consequence, materials' activity and selectivity in $\mathrm{CO}_{2}$ photoreduction.

\section{Materials and Methods}

\subsection{Materials}

The following reagents were used as received: $\mathrm{TiOSO}_{4} \cdot \mathrm{xH}_{2} \mathrm{O} \cdot \mathrm{yH}_{2} \mathrm{SO}_{4}$ ( $\mathrm{Ti}$ assay $>29 \%$ Sigma Aldrich, Milano, Italy), sodium hydroxide (assay > 97\% Carlo Erba, Milano, Italy) and $\mathrm{Cu}\left(\mathrm{NO}_{3}\right)_{2} \cdot 3 \mathrm{H}_{2} \mathrm{O}$ (assay > 99\%, Sigma-Aldrich, Milano, Italy), and 2-propanol (assay 99.8\% Sigma-Aldrich, Milano, Italy). A standard $\mathrm{TiO}_{2}$ reference material (MIRKAT 211) has been purchased by Euro Support s.r.o (Litvínov, Czech Republic). This commercial titania has been chosen as a reference material, since it possesses a large surface area $\left(217 \mathrm{~m}^{2} / \mathrm{g}\right)$, and it is in the anatase form, i.e., the most suitable titania crystalline phase for photocatalytic applications, and it does not contain any trace of carbonaceous species.

\subsection{Synthesis of the Catalysts}

\subsubsection{Titania Synthesis}

The precipitation method has been chosen to synthesise the titania samples. A $1.2 \mathrm{M}$ titanyl sulphate solution and a 9.0 M NaOH solution have been added drop wise and simultaneously to $200 \mathrm{~mL}$ of distilled water under vigorous stirring, in order to keep a neutral $\mathrm{pH}$. Then the $\mathrm{Ti}(\mathrm{OH})_{4}$ suspension has been aged at $60^{\circ} \mathrm{C}$ for $20 \mathrm{~h}$. Afterwards, the precipitated has been filtered and washed with distilled water to remove the sulphate ions. The absence of sulphates has been verified by means of the barium chloride test [96]. The obtained wet $\mathrm{Ti}(\mathrm{OH})_{4}$ has been dried overnight at $110{ }^{\circ} \mathrm{C}$ and calcined at $400{ }^{\circ} \mathrm{C}$ for $4 \mathrm{~h}$ in air flow to obtain $\mathrm{TiO}_{2}$. This sample has been labelled as $\mathrm{TiO}_{2}$.

\subsubsection{Copper Oxide Loading to Titania}

According to a previous work [16], the introduction of copper oxide into titania provides the highest effect on the photoactivity when the $\mathrm{Cu}$ amount is $0.2 \mathrm{wt}$. \%. In particular, incipient wetness impregnation with a copper precursor, namely $\mathrm{Cu}\left(\mathrm{NO}_{3}\right)_{2} \cdot 3 \mathrm{H}_{2} \mathrm{O}$, has been performed on dried $\mathrm{Ti}(\mathrm{OH})_{4}$. Then, the copper-impregnated sample has been calcined at $400{ }^{\circ} \mathrm{C}$ in air flow in order to obtain the $\mathrm{CuO}-\mathrm{TiO}_{2}$ photocatalyst.

\subsubsection{Gold Introduction into Titania}

In this case, the incipient wetness method would not allow us to deposit small gold nanoparticles on the titania surface [97]. Therefore, in order to obtain small gold nanoparticles, gold has been added to titania by using the deposition-precipitation (DP) method, thus maintaining the pH equal to 8.6 [98]. Titanium dioxide has been suspended in an aqueous solution of $\mathrm{HAuCl}_{4} \cdot 3 \mathrm{H}_{2} \mathrm{O}$ for $3 \mathrm{~h}$, while controlling the $\mathrm{pH}$ value by the addition of $\mathrm{NaOH}(0.5 \mathrm{M})$. The Au amount was $0.2 \mathrm{wt}$. \%, the same as in the case of the $\mathrm{CuO}-\mathrm{TiO}_{2}$ photocatalyst, for comparison purposes. After filtration, the samples have been washed with distilled water to remove chlorides. The absence of chlorides was verified by the silver nitrate test. The samples have been dried at $35{ }^{\circ} \mathrm{C}$ overnight and finally calcined in air for $1 \mathrm{~h}$ at $400{ }^{\circ} \mathrm{C}$. The final sample has been labelled $\mathrm{Au}-\mathrm{TiO}_{2}$.

\subsection{Characterization of the Photocatalysts}

The thermal analyses (TG/DTA) have been performed on a NETZSCH STA 409 PC/PG Instrument (Bavaria, Germany) in air flux $(20 \mathrm{~mL} / \mathrm{min})$ using a $10^{\circ} \mathrm{C} / \mathrm{min}$ temperature rate between $25-800{ }^{\circ} \mathrm{C}$.

X-ray Diffraction (XRD) patterns have been collected on a Bruker D8 Advance powder diffractometer with a sealed X-ray tube (copper anode; operating conditions, $40 \mathrm{kV}$ and $40 \mathrm{~mA}$ ) 
(Billerica, MA, USA) and a $\mathrm{Si}(\mathrm{Li})$ solid state detector (Sol- $\mathrm{X}$ ) set to discriminate the $\mathrm{Cu} \mathrm{K} \alpha$ radiation. Apertures of divergence, receiving, and detector slits were $2.0 \mathrm{~mm}, 2.0 \mathrm{~mm}$, and $0.2 \mathrm{~mm}$, respectively. Data scans have been performed in the $2 \theta$ range $5-75^{\circ}$ with $0.02^{\circ}$ step size and counting times of $3 \mathrm{~s} /$ step. Quantitative phase analysis and crystallite size determination have been performed using the Rietveld method as implemented in the TOPAS v.4 program (Bruker AXS, Billerica, MA, USA) using the fundamental parameters approach for line-profile fitting. The determination of the crystallite size was accomplished by the Double-Voigt approach and calculated as volume-weighted mean column heights based on integral breadths of peaks.

$\mathrm{N}_{2}$ adsorption-desorption isotherms at $196^{\circ} \mathrm{C}$ were performed using a Micromeritics ASAP 2000 analyser (Norcross, GA, USA) to obtain information on the surface properties. All samples were previously outgassed at $200^{\circ} \mathrm{C}$ for $2 \mathrm{~h}$. The mesopore volume was measured as the adsorbed amount of $\mathrm{N}_{2}$ after capillary condensation. The surface area was evaluated using the standard BET [99] equation, and the pore size distribution was obtained using the $\mathrm{BJH}$ method applied to the isotherm desorption branch [100].

The real amount of copper and gold in the promoted catalysts was determined by flame atomic absorption spectroscopy (FAAS) using a PerkinElmer Analyst 100 (Waltham, MA, USA).

Temperature programmed reduction (TPR) experiments were carried out in a lab-made equipment; each sample $\left(50 \mathrm{mg}\right.$ ) was heated at $10{ }^{\circ} \mathrm{C} / \mathrm{min}$ from $25{ }^{\circ} \mathrm{C}$ to $800{ }^{\circ} \mathrm{C}$ in a $5 \% \mathrm{H}_{2} /$ Ar reducing mixture $\left(40 \mathrm{~mL} \cdot \mathrm{min}^{-1} \mathrm{STP}\right)$. The effluent gases were analysed by a Gow-Mac TCD detector (Bethlehem, PA, USA) using a magnesium perchlorate trap to stop $\mathrm{H}_{2} \mathrm{O}$.

Diffuse reflectance UV-Vis-NIR spectra were collected at r.t. on a Varian Cary 5000 spectrophotometer (Palo Alto, CA, USA) with an integrating sphere attachment using $\mathrm{BaSO}_{4}$ powder as an internal reference, working in the $50,000-4000 \mathrm{~cm}^{-1}$ range. UV-Vis-NIR spectra of the as prepared samples are reported in the Kubelka-Munk function $\left[f\left(R_{\infty}\right)=\left(1-R_{\infty}\right)^{2} / 2 R_{\infty} ; R_{\infty}=\right.$ reflectance of an "infinitely thick" layer of the sample [101]. The layer of powder sample was made sufficiently thick such that all incident light was absorbed or scattered before reaching the back surface of the sample holder. Typically, a thickness of 1-3 mm was required.

The samples in the form of powders were placed in a quartz cell, allowing treatments in controlled atmosphere and temperature. The band gap energy (Eg) of the catalysts was determined by the intercept of a linear fit to the absorption edge, and it can be estimated using the standard equation, which is based on the relationship between frequency $(c / \lambda)$ and photon energy $(E g=1240 / \lambda)$.

The FTIR analyses were performed using a Perkin Elmer 2000 spectrometer (equipped with a cryogenic MCT detector) (Waltham, MA, USA). As for the analyses at increasing temperature, each sample, in the form of self-supporting pellet, was placed in an AABSPEC 2000 cell allowing to run the spectra in situ in controlled atmosphere and temperature. The samples were outgassed from room temperature up to $150^{\circ} \mathrm{C}$. As for the measurements of $\mathrm{CO}_{2}$ adsorption at room temperature, the samples were submitted to outgassing at r.t. for $1 \mathrm{~h}$ in order to remove water, that is, adsorbed at the surface due to the exposition to air. The spectrum of the sample before the inlet of $\mathrm{CO}_{2}$ was subtracted from each spectrum, and all spectra were normalised with respect to the density of the pellets.

\subsection{Photoactivity Tests}

The catalytic apparatus was reported in a previous work [16]; however, in this paper two new experimental setups, such as the reactor geometry and the catalyst introduction, were used. In the former case a tubular borate glass fixed bed reactor (length $40 \mathrm{~mm}$, diameter $4 \mathrm{~mm}$ ) was exploited. The catalyst $\left(400 \mathrm{mg}\right.$ ) was introduced as small particles with size $0.2-0.3 \mathrm{~mm}$. In the latter case, the $\mathrm{CO}_{2}$ photoreduction was performed using a borate glass thin film reactor (length $33 \mathrm{~mm}$, height $18 \mathrm{~mm}$, thickness $2 \mathrm{~mm})$. Here, the catalyst $(10 \mathrm{mg}$ ) was inserted by depositing the catalyst suspended in 2-propanol on the light-exposed side of the reactor. 2-propanol can act as a hydrogen donor leading to data misinterpretation. To overcome this problem, drying at $110^{\circ} \mathrm{C}$ for $1 \mathrm{~h}$ was sufficient to eliminate all residues of $\mathrm{CO}_{2}$ photoreduction. 
The samples were illuminated using a $125 \mathrm{~W}$ mercury UVA lamp (purchased from Helios Italquartz s.r.l (Cambiago, Italy). with emission range 315-400 shielded by a special tubular quartz, to select the $366 \mathrm{~nm}$ wavelength), with an average irradiance of $50 \mathrm{~W} \cdot \mathrm{m}^{-2}$. It has been observed that irradiance in front of the reactor is the same as behind it; thus, it is possible to state that the reactor walls do not adsorb the light. In performed tests, neither heating nor cooling is used. UV lamp provides a stable and constant temperature of $40{ }^{\circ} \mathrm{C}$ on the photocatalytic surface. Afterwards, a gaseous mixture of carbon dioxide and water has flown through the reactor. Compressed $\mathrm{CO}_{2}(99.99 \%)$ regulated by a mass flow controller was carried through a water bubbler kept at $40{ }^{\circ} \mathrm{C}$ to generate $\mathrm{CO}_{2}$ and $\mathrm{H}_{2} \mathrm{O}$ vapour mixture $\left(13.3 \mathrm{CO}_{2} / \mathrm{H}_{2} \mathrm{O}\right.$ molar ratio). The reactor was closed when the system reached the equilibrium state, and this point was taken as the beginning of the reaction. Therefore, the reaction was not performed under a continuous gas flow, but it took place in static conditions. A total of $9.2 \mu \mathrm{mol}$ of $\mathrm{CO}_{2}$ and $0.7 \mu \mathrm{mol}$ of $\mathrm{H}_{2} \mathrm{O}$ were present within the sealed reactor. In all catalytic tests, the reaction time was $6 \mathrm{~h}$.

The reaction products were analyzed by a gas chromatograph (HP G1540A) equipped with a Porapak Q column and a TCD detector. Activity results are expressed in turn over numbers (TONs) in $\mu \mathrm{mol} \cdot \mathrm{g}_{\mathrm{cat}}{ }^{-1}$, as commonly used in literature [102,103], with an average error of $10 \%$. Quantum yield $(\Phi)$ was calculated according to IUPAC recommendations [104], as reported in Equations (1) and (2).

$$
\begin{gathered}
\Phi(\%)=\frac{\text { required } \mathrm{e}^{-} \cdot \mathrm{CH} \mathrm{H}_{4}(\mathrm{~mol})}{\text { incident photons }(\mathrm{mol})} \times 100 \\
\Phi(\%)=\frac{8 \cdot \mathrm{CH}_{4}(\mathrm{~mol}) \cdot \operatorname{Irr}\left(\mathrm{W} \cdot \mathrm{m}^{-2}\right) \cdot t(\mathrm{~s}) \cdot \mathrm{A}\left(\mathrm{m}^{2}\right) \cdot \lambda(\mathrm{m}) \cdot \mathrm{N}_{A}\left(\mathrm{~mol}^{-1}\right)}{h(\mathrm{~J} \cdot \mathrm{s}) \cdot \mathrm{c}\left(\mathrm{m} \cdot \mathrm{s}^{-1}\right)} \times 100
\end{gathered}
$$

where 8 is the number of required electrons for $\mathrm{CO}_{2}$ reduction to $\mathrm{CH}_{4}$, Irr is the irradiance, $t$ is reaction time, $A$ is the illuminated area, $\lambda$ radiation wavelength, $N_{A}$ is Avogadro's number, $h$ is Planck's constant, and $c$ is speed of light.

\section{Conclusions}

The development of an efficient technology for carbon dioxide conversion into solar fuel relies on an integrated and interdisciplinary "catalysis by design" approach covering different expertise areas, such as fundamental science and applied engineering. In this paper, two main carbon dioxide photoreduction drawbacks, namely light harvesting and process selectivity, were investigated.

Light harvesting was enormously implemented by reactor design; the choice of a thin film reactor enhanced methane enormously, leading to comparable results with those found in literature, despite considerably milder conditions, particularly in terms of irradiance.

On the contrary, the material design was fundamental to developing an opportunely designed catalytic system to control the selectivity to the desired product, i.e., methane. Modification of electronic and surface properties allowed us to reach this goal. On one side, the enhanced charge separation observed for $\mathrm{Au}-\mathrm{TiO}_{2}$ seems to negatively affect the activity, resulting in a less negative $\mathrm{CB}$, thus less efficient in $\mathrm{CO}_{2}$ photoreduction.

On the other side, $\mathrm{CO}_{2}$ adsorption on the catalytic surface represents a critical step that still deserves as much attention as developing greener and highly active catalysts. The $\mathrm{CuO}-\mathrm{TiO}_{2}$ photocatalyst matches all these requirements, proving to be more active and selective than the $\mathrm{Au}-\mathrm{TiO}_{2}$ material. The reasons for the enhanced photoactivity could be related to the presence and the abundance of surface sites able to efficiently adsorb and react with the $\mathrm{CO}_{2}$ reactant.

Acknowledgments: The authors thank Tania Fantinel ( $\mathrm{Ca}^{\prime}$ Foscari University of Venice) for the excellent technical assistance. The financial support of Regione Veneto (project number: 2120/10/2121/2015) is gratefully acknowledged.

Author Contributions: M.S. and A.O. conceived and designed the experiments. E.G. conceived materials synthesis formulation and performed physisorption analyses. P.P. performed the experiments. M.M. performed 
DRS and FTIR analyses and provided data elaboration. G.C. contributed with XRD characterization. M.S., A.O., E.G., and M.M. wrote the manuscript.

Conflicts of Interest: The authors declare no conflict of interest. The founding sponsors had no role in the design of the study; in the collection, analyses, or interpretation of data; in the writing of the manuscript; or in the decision to publish the results.

\section{References}

1. Wang, Q.; Wu, S.D.; Zeng, Y.E.; Wu, B.W. Exploring the relationship between urbanization, energy consumption, and $\mathrm{CO}_{2}$ emissions in different provinces of China. Renew. Sustain. Energy Rev. 2016, 54, 1563-1579. [CrossRef]

2. Höök, M.; Tang, M.X. Depletion of fossil fuels and anthropogenic climate change: A review. Energy Policy 2013, 52, 797-809. [CrossRef]

3. Dai, H.; Xie, X.; Xie, Y.; Liu, J.; Masui, T. Green growth: The economic impacts of large-scale renewable energy development in China. Appl. Energy 2016, 162, 435-449. [CrossRef]

4. Framework Convention on Climate Change (FCCC). Paris Agreement; Document FCCC/CP/2015/L.9/Rev.1; FCCC: Paris, France, 2015.

5. Aresta, M.; Dibenedetto, A.; Angelini, A. The changing paradigm in $\mathrm{CO}_{2}$ utilization. J. $\mathrm{CO}_{2}$ Util. 2013, 3, 65-73. [CrossRef]

6. Sakakura, T.; Choi, J.-C.; Yasuda, H. Transformation of Carbon Dioxide. Chem. Rev. 2007, 107, $2365-2387$. [CrossRef] [PubMed]

7. Roy, S.; Varghese, O.; Paulose, M.; Grimes, C. Toward Solar Fuels: Photocatalytic Conversion of Carbon Dioxide to Hydrocarbons. ACS Nano 2010, 3, 1259-1278. [CrossRef] [PubMed]

8. Ola, O.; Maroto-Valer, M. Review of material design and reactor engineering on $\mathrm{TiO}_{2}$ photocatalysis for $\mathrm{CO}_{2}$ reduction. J. Photochem. Photobiol. C 2015, 24, 16-42. [CrossRef]

9. Tahir, M.; Amin, N. Recycling of carbon dioxide to renewable fuels by photocatalysis: Prospects and challenges. Renew. Sustain. Energy Rev. 2013, 25, 560-579. [CrossRef]

10. Akhter, P.; Hussain, M.; Saracco, G.; Russo, N. Novel nanostructured-TiO 2 materials for the photocatalytic reduction of $\mathrm{CO}_{2}$ greenhouse gas to hydrocarbons and syngas. Fuel 2015, 149, 55-65. [CrossRef]

11. Neatu, S.; Maciá-Agulló, J.; Garcia, H. Solar Light Photocatalytic $\mathrm{CO}_{2}$ Reduction: General Considerations and Selected Bench-Mark Photocatalysts. Int. J. Mol. Sci. 2014, 15, 5246-5262. [CrossRef] [PubMed]

12. Marszewski, M.; Cao, S.; Yu, J.; Jaronec, M. Semiconductor-based photocatalytic $\mathrm{CO}_{2}$ conversion. Mater. Horiz. 2015, 2, 261-278. [CrossRef]

13. Centi, G.; Perathoner, S. Opportunities and prospects in the chemical recycling of carbon dioxide to fuels. Catal. Today 2009, 148, 191-205. [CrossRef]

14. Izumi, Y. Recent advances in the photocatalytic conversion of carbon dioxide to fuels with water and/or hydrogen using solar energy and beyond. Coord. Chem. Rev. 2013, 257, 171-186. [CrossRef]

15. Sastre, F.; Puga, A.; Liu, L.; Corma, A.; Garcia, H. Complete Photocatalytic Reduction of $\mathrm{CO}_{2}$ to Methane by $\mathrm{H}_{2}$ under Solar Light Irradiation. J. Am. Chem. Soc. 2014, 136, 6798-6801. [CrossRef] [PubMed]

16. Olivo, A.; Trevisan, V.; Ghedini, E.; Pinna, F.; Bianchi, C.L.; Naldoni, A.; Cruciani, G.; Signoretto, M. $\mathrm{CO}_{2}$ photoreduction with water: Catalyst and process investigation. J. $\mathrm{CO}_{2}$ Util. 2015, 12, 86-94. [CrossRef]

17. Peng, Y.; Yeh, Y.; Shah, S.; Huang, C.P. Concurrent photoelectrochemical reduction of $\mathrm{CO}_{2}$ and oxidation of methyl orange using nitrogen-doped $\mathrm{TiO}_{2}$. Appl. Catal. B 2012, 123, 414-423. [CrossRef]

18. Lee, W.S.; Liao, C.H.; Tsai, M.F.; Huang, C.W.; Wu, J.C.S. A novel twin reactor for $\mathrm{CO}_{2}$ photoreduction to mimic artificial photosynthesis. Appl. Catal. B 2013, 132-133, 445-451. [CrossRef]

19. De Richter, R.; Ming, T.; Caillol, S. Fighting global warming by photocatalytic reduction of $\mathrm{CO}_{2}$ using giant photocatalytic reactors. Renew. Sustain. Energy Rev. 2013, 19, 82-106. [CrossRef]

20. Ni, M.; Leung, M.; Leung, D.; Sumathy, K.A. review and recent developments in photocatalytic water-splitting using $\mathrm{TiO}_{2}$ for hydrogen production. Renew. Sustain. Energy Rev. 2007, 11, 401-425. [CrossRef]

21. Graves, C.; Ebbsen, S.; Morgensen, M.; Lackner, K.S. Sustainable hydrocarbon fuels by recycling $\mathrm{CO}_{2}$ and $\mathrm{H}_{2} \mathrm{O}$ with renewable or nuclear energy. Renew. Sustain. Energy Rev. 2011, 15, 1-23. [CrossRef] 
22. Arawaka, H.; Aresta, M.; Armor, J.N.; Barteau, M.A.; Beckman, E.J.; Bell, A.T.; Bercaw, J.E.; Creutz, C.; Dinjus, E.; Dixon, D.; et al. Catalysis Research of Relevance to Carbon Management: Progress, Challenges, and Opportunities. Chem. Rev. 2001, 101, 953-996. [CrossRef]

23. Dhakshinamoorthy, A.; Navalon, S.; Corma, A.; Garcia, H. Photocatalytic $\mathrm{CO}_{2}$ reduction by $\mathrm{TiO}_{2}$ and related titanium containing solids. Energy Environ. Sci. 2011, 5, 9217-9233. [CrossRef]

24. Liu, G.; Hoivik, N.; Wang, K.; Jakobsen, H. Engineering $\mathrm{TiO}_{2}$ nanomaterials for $\mathrm{CO}_{2}$ conversion/solar fuels. Sol. Energy Mater. Sol. Cells 2012, 105, 53-68. [CrossRef]

25. Indrakanti, V.P.; Kubicki, J.D.; Schobert, H.H. Photoinduced activation of $\mathrm{CO}_{2}$ on Ti-based heterogeneous catalysts: Current state, chemical physics-based insights and outlook. Energy Environ. Sci. 2009, 2, 745-758. [CrossRef]

26. Carp, O.; Hiusman, C.L.; Reller, A. Photoinduced reactivity of titanium dioxide. Prog. Solid State Chem. 2004, 32, 33-177. [CrossRef]

27. Gupta, S.M.; Tripathi, M. A review of $\mathrm{TiO}_{2}$ nanoparticles. Chin. Sci. Bull. 2011, 56, 1639-1657. [CrossRef]

28. Inoue, T.; Fujishima, A.; Konishi, K.; Honda, K. Photoelectrocatalytic reduction of carbon dioxide in aqueous suspensions of semiconductor powders. Nature 1979, 277, 637-638. [CrossRef]

29. Karamian, E.; Sharifnia, S. On the general mechanism of photocatalytic reduction of $\mathrm{CO}_{2}$. J. $\mathrm{CO}_{2}$ Util. 2016, 16, 194-203. [CrossRef]

30. Do, J.Y.; Im, Y.; Kwak, B.S.; Kim, J.-Y.; Kang, M. Dramatic $\mathrm{CO}_{2}$ photoreduction with $\mathrm{H}_{2} \mathrm{O}$ vapors for $\mathrm{CH}_{4}$ production using the $\mathrm{TiO}_{2}$ (bottom) $/ \mathrm{Fe}-\mathrm{TiO}_{2}$ (top) double-layered films. Chem. Eng. J. 2015, 275, $288-297$. [CrossRef]

31. Nikokavoura, A.; Trapalis, C. Alternative photocatalysts to $\mathrm{TiO}_{2}$ for the photocatalytic reduction of $\mathrm{CO}_{2}$. Appl. Surf. Sci. 2017, 391, 149-174. [CrossRef]

32. Vereb, G.; Manczinger, L.; Bozso, G.; Sienkiewicz, A.; Forro, L.; Mogyorosi, K.; Hernadi, K.; Dombi, A. Comparison of the photocatalytic efficiencies of bare and doped rutile and anatase $\mathrm{TiO}_{2}$ photocatalysts under visible light for phenol degradation and E. coli inactivation. Appl. Catal. B 2013, 129, 566-574. [CrossRef]

33. Marschall, R.; Wang, L. Non-metal doping of transition metal oxides for visible-light photocatalysis. Catal. Today 2014, 225, 111-135. [CrossRef]

34. Pelaez, M.; Nolan, N.T.; Pillai, S.C.; Seery, M.K.; Falaras, P.; Kontos, A.G.; Dunlop, P.S.M.; Hamilton, J.W.J.; Byrne, J.A.; O'Shea, K.; et al. A review on the visible light active titanium dioxide photocatalysts for environmental applications. Appl. Catal. B 2012, 125, 331-349. [CrossRef]

35. Xu, H.; Ouyang, S.; Liu, L.; Umezawa, N.; Ye, J. Porous-structured $\mathrm{Cu}_{2} \mathrm{O} / \mathrm{TiO}_{2}$ nanojunction material toward efficient $\mathrm{CO}_{2}$ photoreduction. J. Mater. Chem. A 2014, 2, 12462-12661. [CrossRef] [PubMed]

36. Sun, T.; Liu, E.; Fan, J.; Hu, X.; Wu, F.; Hou, W. High photocatalytic activity of hydrogen production from water over Fe doped and $\mathrm{Ag}$ deposited anatase $\mathrm{TiO}_{2}$ catalyst synthesized by solvothermal method. Chem. Eng. J. 2013, 228, 896-906. [CrossRef]

37. Linsebigler, A.; Lu, G.; Yates, J. Photocatalysis on $\mathrm{TiO}_{2}$ Surfaces: Principles, Mechanisms, and Selected Results. Chem. Rev. 1995, 95, 735-758. [CrossRef]

38. Janus, M.; Inagaki, M.; Tryba, B.; Toyoda, M.; Morawski, A.W. New preparation of a carbon-TiO 2 photocatalyst by carbonization of $n$-hexane deposited on $\mathrm{TiO}_{2}$. Appl. Catal. B 2006, 63, 272-276. [CrossRef]

39. Kang, I.; Zhang, Q.; Yin, S.; Sato, T.; Saito, F. Preparation of a visible sensitive carbon doped $\mathrm{TiO}_{2}$ photo-catalyst by grinding $\mathrm{TiO}_{2}$ with ethanol and heating treatment. Appl. Catal. B 2008, 82, 81-87. [CrossRef]

40. Das, S.; Wan Daud, W. Photocatalytic $\mathrm{CO}_{2}$ transformation into fuel: A review on advances in photocatalyst and photoreactor. Renew. Sustain. Energy Rev. 2014, 39, 765-805. [CrossRef]

41. Diebold, U. The surface science of titanium dioxide. Surf. Sci. Rep. 2003, 48, 53-229. [CrossRef]

42. Li, K.; An, X.; Park, K.H.; Khraisheh, M.; Tang, J. A critical review of $\mathrm{CO}_{2}$ photoconversion: Catalysts and reactors. Catal. Today 2014, 224, 3-12. [CrossRef]

43. Meng, X.; Ouyang, S.; Kako, T.; Li, P.; Yu, Q.; Wang, T.; Ye, J. Photocatalytic $\mathrm{CO}_{2}$ conversion over alkali modified $\mathrm{TiO}_{2}$ without loading noble metal cocatalyst. Chem. Commun. 2014, 50, 11517-11519. [CrossRef] [PubMed]

44. Ohtani, B. Photocatalysis by inorganic solid materials. Inorg. Photochem. 2011, 63, 395-430. [CrossRef]

45. Bai, S.; Yin, W.; Wang, L.; Li, Z.; Xiong, Y. Surface and interface design in cocatalysts for photocatalytic water splitting and $\mathrm{CO}_{2}$ reduction. RCS Adv. 2016, 6, 57446-57463. [CrossRef] 
46. Wang, Y.; Li, B.; Zhang, C.; Cui, L.; Kang, S.; Li, X.; Zhou, L. Ordered mesoporous $\mathrm{CeO}_{2}-\mathrm{TiO}_{2}$ composites: Highly efficient photocatalysts for the reduction of $\mathrm{CO}_{2}$ with $\mathrm{H}_{2} \mathrm{O}$ under simulated solar irradiation. Appl. Catal. B 2013, 130, 277-284. [CrossRef]

47. Malato, S.; Fernandez-Ibanez, P.; Malodato, M.I.; Blanco, J.; Gerjakm, W. Decontamination and disinfection of water by solar photocatalysis: Recent overview and trends. Catal. Today 2009, 147, 1-59. [CrossRef]

48. Yuan, L.; $\mathrm{Xu}$, Y.J. Photocatalytic conversion of $\mathrm{CO}_{2}$ into value-added and renewable fuels. Appl. Surf. Sci. 2015, 342, 154-167. [CrossRef]

49. Liu, L.; Gao, F.; Zhao, H.; Li, Y. Tailoring $\mathrm{Cu}$ valence and oxygen vacancy in $\mathrm{Cu} / \mathrm{TiO}_{2}$ catalysts for enhanced $\mathrm{CO}_{2}$ photoreduction efficiency. Appl. Catal. B 2013, 134-135, 349-358. [CrossRef]

50. Qin, S.; Xin, F.; Liu, Y.; Yin, X.; Ma, W. Photocatalytic reduction of $\mathrm{CO}_{2}$ in methanol to methyl formate over $\mathrm{CuO}-\mathrm{TiO}_{2}$ composite catalysts. J. Colloid Interface Sci. 2011, 356, 257-261. [CrossRef] [PubMed]

51. Isahak, W.N.R.W.; Ramli, Z.A.C.; Ismail, M.W.; Ismail, K.; Yosup, R.M.; Hisham, M.W.M.; Yarmo, M.A. Adsorption-desorption of $\mathrm{CO}_{2}$ on different type of copper oxides surfaces: Physical and chemical attractions studies. J. $\mathrm{CO}_{2}$ Util. 2013, 2, 8-15. [CrossRef]

52. Ghosh, S.K.; Pal, T. Interparticle Coupling Effect on the Surface Plasmon Resonance of Gold Nanoparticles: From Theory to Applications. Chem. Rev. 2007, 107, 4797-4862. [CrossRef] [PubMed]

53. Kaur, R.; Pal, B. Size and shape dependent attachments of Au nanostructures to $\mathrm{TiO}_{2}$ for optimum reactivity of $\mathrm{Au}-\mathrm{TiO}_{2}$ photocatalysis. J. Mol. Catal. A 2012, 355, 39-43. [CrossRef]

54. Tahir, B.; Tahir, M.; Amin, N. Photocatalytic $\mathrm{CO}_{2}$ conversion over $\mathrm{Au} / \mathrm{TiO}_{2}$ nanostructures for dynamic production of clean fuels in a monolith photoreactor. Clean Technol. Environ. Policy 2016, 18, 2147-2160. [CrossRef]

55. Silva, C.; Juarez, R.; Marino, T.; Molinari, R.; Garcia, H. Influence of excitation wavelength (UV or visible light) on the photocatalytic activity of titania containing gold nanoparticles for the generation of hydrogen or oxygen from water. J. Am. Chem. Soc. 2011, 133, 595-602. [CrossRef] [PubMed]

56. Primo, A.; Corma, A.; Garcìa, H. Titania supported gold nanoparticles as photocatalyst. Phys. Chem. Chem. Phys. 2011, 13, 886-910. [CrossRef] [PubMed]

57. Crisan, D.; Dragan, N.; Raileanu, M.; Crisan, M.; Ianculescu, A.; Luca, D.; Nastuta, A.; Mandare, D. Structural study of sol-gel Au/ $\mathrm{TiO}_{2}$ films from nanopowders. Appl. Surf. Sci. 2011, 257, 4227-4231. [CrossRef]

58. Korologos, C.A.; Nikolaki, M.D.; Zerva, C.N.; Philippopoulos, C.J.; Poupoulos, S.G. Photocatalytic oxidation of benzene, toluene, ethylbenzene and $\mathrm{m}$-xylene in the gas-phase over $\mathrm{TiO}_{2}$-based catalysts. J. Photochem. Photobiol. A 2012, 244, 24-31. [CrossRef]

59. Daous, M.; Iliev, V.; Petrov, L. Gold-modified $\mathrm{N}$-doped $\mathrm{TiO}_{2}$ and $\mathrm{N}$-doped $\mathrm{WO}_{3} / \mathrm{TiO}_{2}$ semiconductors as photocatalysts for UV-visible light destruction of aqueous 2,4,6-trinitrotoluene solution. J. Mol. Catal. A 2014, 392, 194-201. [CrossRef]

60. Fujishima, A.; Zhang, X.; Tryk, D. Heterogeneous photocatalysis: From water photolysis to applications in environmental cleanup. Int. J. Hydrogen Energy 2007, 32, 2664-2672. [CrossRef]

61. Camarillo, R.; Tostòn, S.; Martìnez, F.; Jimènez, C.; Rincòn, J. Enhancing the photocatalytic reduction of $\mathrm{CO}_{2}$ through engineering of catalysts with high pressure technology: $\mathrm{Pd} / \mathrm{TiO}_{2}$ photocatalysts. J. Supercrit. Fluids 2017, 123, 18-27. [CrossRef]

62. Corma, A.; Garcia, H. Photocatalytic reduction of $\mathrm{CO}_{2}$ for fuel production: Possibilities and challenges. J. Catal. 2013, 308, 168-175. [CrossRef]

63. Tahir, M.; Tahir, B.; Amin, N.; Zakaria, Z.Y. Photo-induced reduction of $\mathrm{CO}_{2}$ to $\mathrm{CO}$ with hydrogen over plasmonic Ag-NPs $/ \mathrm{TiO}_{2}$ NWs core/shell hetero-junction under UV and visible light. J. $\mathrm{CO}_{2}$ Util. 2017, 18, 250-260. [CrossRef]

64. Naldoni, A.; D’Arienzo, M.; Altomare, M.; Marelli, M.; Scotti, R.; Morazzoni, F.; Selli, E.; Del Santo, V. Pt and $\mathrm{Au} / \mathrm{TiO}_{2}$ photocatalysts for methanol reforming: Role of metal nanoparticles in tuning charge trapping properties and photoefficiency. Appl. Catal. B 2013, 130, 239-248. [CrossRef]

65. Collado, L.; Reynal, A.; Coronado, J.M.; Serrano, D.P.; Durrant, J.R.; de la Pena O'Shea, V.A. Effect of Au surface plasmon nanoparticles on the selective $\mathrm{CO}_{2}$ photoreduction to $\mathrm{CH}_{4}$. Appl. Catal. B 2015, 178, 177-185. [CrossRef]

66. Lo, C.C.; Hung, C.H.; Yuan, C.S.; Wu, J.F. Parameter Effects and Reaction Pathways of Photoreduction of $\mathrm{CO}_{2}$ over $\mathrm{TiO}_{2} / \mathrm{SO}_{4}{ }^{2-}$ Photocatalyst. Sol. Energy Mater. Sol. Cells 2007, 91, 1765-1774. [CrossRef] 
67. Wang, T.; Yang, L.; Du, X.; Yang, Y. Numerical investigation on $\mathrm{CO}_{2}$ photocatalytic reduction in optical fiber monolith reactor. Energy Convers. Manag. 2013, 65, 299-307. [CrossRef]

68. Guan, G.; Kida, T.; Harada, T.; Iasayama, M.; Yoshida, A. Photoreduction of carbon dioxide with water over $\mathrm{K}_{2} \mathrm{Ti}_{6} \mathrm{O}_{13}$ photocatalyst combined with $\mathrm{Cu} / \mathrm{ZnO}$ catalyst under concentrated sunlight. Appl. Catal. A 2003, 249, 11-18. [CrossRef]

69. Bazzo, A.; Urawaka, A. Origin of photocatalytic activity in continuous gas phase $\mathrm{CO}_{2}$ reduction over $\mathrm{Pt} / \mathrm{TiO}$. ChemSusChem 2013, 6, 2095-2102. [CrossRef] [PubMed]

70. Fang, B.; Xing, Y.; Bonakdapour, A.; Zhang, S.; Wilkinson, D.P. Hierarchical CuO-TiO 2 Hollow Microspheres for Highly Efficient Photodriven Reduction of $\mathrm{CO}_{2}$ to $\mathrm{CH}_{4}$. ACS Sustain. Chem. Eng. 2015, 3, 2381-2388. [CrossRef]

71. Zhao, C.; Krall, A.; Zhao, H.; Zhang, Q.; Li, Y. Ultrasonic spray pyrolysis synthesis of $\mathrm{Ag} / \mathrm{TiO}_{2}$ nanocomposite photocatalysts for simultaneous $\mathrm{H}_{2}$ production and $\mathrm{CO}_{2}$ reduction. Int. J. Hydrogen Energy 2012, 37, 9967-9976. [CrossRef]

72. Grigioni, I.; Dozzi, M.V.; Bernareggi, M.; Chiarello, G.L.; Selli, E. Photocatalytic $\mathrm{CO}_{2}$ reduction vs. $\mathrm{H}_{2}$ production: The effects of surface carbon-containing impurities on the performance of $\mathrm{TiO}_{2}$-based photocatalysts. Catal. Today 2017, 281, 214-220. [CrossRef]

73. Camarillo, R.; Tostòn, S.; Martìnez, F.; Jimènez, C.; Rincòn, J. Preparation of $\mathrm{TiO}_{2}$-based catalysts with supercritical fluid technology: Characterization and photocatalytic activity in $\mathrm{CO}_{2}$ reduction. J. Chem. Technol. Biotechnol. 2017, 92, 1710-1720. [CrossRef]

74. Camarillo, R.; Tostòn, S.; Martìnez, F.; Jimènez, C.; Rincòn, J. Supercritical synthesis of platinum-modified titanium dioxide for solar fuel production from carbon dioxide. Chin. J. Catal. 2017, 38, 636-650. [CrossRef]

75. Tan, L.; Ong, W.; Chai, S.; Rahman, A. Photocatalytic reduction of $\mathrm{CO}_{2}$ with $\mathrm{H}_{2} \mathrm{O}$ over graphene oxide-supported oxygen-rich $\mathrm{TiO}_{2}$ hybrid photocatalyst under visible light irradiation: Process and kinetic studies. Chem. Eng. J. 2017, 308, 248-255. [CrossRef]

76. Ola, O.; Maroto-Valer, M. Synthesis, characterization and visible light photocatalytic activity of metal based $\mathrm{TiO}_{2}$ monoliths for $\mathrm{CO}_{2}$ reduction. Chem. Eng. J. 2016, 283, 1244-1253. [CrossRef]

77. Wu, J.C.S.; Huang, C.W. In situ DRIFTS study of photocatalytic $\mathrm{CO}_{2}$ reduction under UV irradiation. Front. Chem. Eng. China 2010, 4, 120-126. [CrossRef]

78. Shibata, T.; Irie, H.; Ohmori, M.; Nakajima, A.; Watanabe, T.; Hashimoto, K. Comparison of photochemical properties of brookite and anatase $\mathrm{TiO}_{2}$ films. Phys. Chem. Chem. Phys. 2004, 6, 1359-1362. [CrossRef]

79. Shelimov, B.N.; Tolkachev, N.N.; Tkachenko, O.P.; Baeve, G.N.; Klemen-tiev, K.V.; Stakheev, A.Y.; Kazansky, V.B. Enhancement effect of $\mathrm{TiO}_{2}$ dispersion over alumina on the photocatalytic removal of $\mathrm{NO}_{x}$ admixtures from $\mathrm{O}_{2}-\mathrm{N}_{2}$ flow. J. Photochem. Photobiol. A 2008, 195, 81-88. [CrossRef]

80. Olivo, A.; Ghedini, E.; Signoretto, M.; Compagnoni, M.; Rossetti, I. Liquid vs. Gas Phase $\mathrm{CO}_{2}$ Photoreduction Process: Which Is the Effect of the Reaction Medium? Energies 2017, 10, 1394. [CrossRef]

81. Tahir, M.; Amin, N. Photocatalytic $\mathrm{CO}_{2}$ reduction with $\mathrm{H}_{2} \mathrm{O}$ vapors using montmorillonite/TiO $\mathrm{O}_{2}$ supported microchannel monolith photoreactor. Chem. Eng. J. 2013, 230, 314-327. [CrossRef]

82. Nguyen, T.; Wu, J.C.S. Photoreduction of $\mathrm{CO}_{2}$ in an optical-fiber photoreactor: Effects of metals addition and catalyst carrier. Appl. Catal. A 2008, 335, 112-120. [CrossRef]

83. Menegazzo, F.; Signoretto, M.; Marchese, D.; Pinna, F.; Manzoli, M. Structure-Activity relationships of $\mathrm{Au} / \mathrm{ZrO}_{2}$ catalysts for 5-hydroxymethylfurfural oxidative esterification: Effects of zirconia sulphation on gold dispersion, position and shape. J. Catal. 2015, 326, 1-8. [CrossRef]

84. Manzoli, M.; Menegazzo, F.; Signoretto, M.; Cruciani, G.; Pinna, F. Effects of synthetic parameters on the catalytic performance of $\mathrm{Au} / \mathrm{CeO}_{2}$ for furfural oxidative esterification. J. Catal. 2015, 330, 465-473. [CrossRef]

85. Yashnik, S.; Ismagilov, Z.; Anufrienko, V. Catalytic properties and electronic structure of copper ions in Cu-ZSM-5. Catal. Today 2005, 110, 310-322. [CrossRef]

86. Bravo-Suárez, J.J.; Subramaniam, B.; Chaudhari, R.V. Ultraviolet-Visible Spectroscopy and Temperature-Programmed Techniques as Tools for Structural Characterization of $\mathrm{Cu}$ in $\mathrm{CuMgAlO}_{x}$ Mixed Metal Oxides. J. Phys. Chem. C 2012, 116, 18207-18221. [CrossRef]

87. Anpo, M.; Yamashita, H.; Ichihashi, Y.; Ehara, S. Photocatalytic reduction of $\mathrm{CO}_{2}$ with $\mathrm{H}_{2} \mathrm{O}$ on various titanium oxide catalysts. J. Electroanal. Chem. 1995, 396, 21-26. [CrossRef]

88. Carneiro, J.T.; Yang, C.C.; Moma, J.A.; Moulijin, J.A.; Mul, G. How gold deposition affects anatase performance in the photo-catalytic oxidation of cyclohexane. Catal. Lett. 2009, 129, 12-19. [CrossRef] 
89. Martra, G. Lewis acid and base sites at the surface of microcrystalline $\mathrm{TiO}_{2}$ anatase: Relationships between surface morphology and chemical behaviour. Appl. Catal. A 2000, 200, 275-285. [CrossRef]

90. Morterra, C. An infrared spectroscopic study of anatase properties. Part 6-Surface hydration and strong Lewis acidity of pure and sulphate-doped preparations. J. Chem. Soc. Faraday Trans. 1 1988, 84, 1617-1637. [CrossRef]

91. Cerrato, G.; Marchese, L.; Morterra, C. Structural and morphological modifications of sintering microcrystalline $\mathrm{TiO}_{2}$ : An XRD, HRTEM and FTIR study. Appl. Surf. Sci. 1993, 70-71, 200-205. [CrossRef]

92. Morterra, C.; Cerrato, G.; Emanuel, C. End-on surface coordinated (adsorbed) $\mathrm{CO}_{2}:$ A specific ligand for surface Lewis acidic centres. Mater. Chem. Phys. 1991, 29, 447-456. [CrossRef]

93. Busca, G.; Lorenzelli, V. Infrared spectroscopic identification of species arising from reactive adsorption of carbon oxides on metal oxide surfaces. Mater. Chem. 1982, 7, 89-126. [CrossRef]

94. Baltrusaitis, J.; Schuttlefield, J.; Zeitler, E.; Grassian, V.H. Carbon dioxide adsorption on oxide nanoparticle surfaces. Chem. Eng. J. 2011, 170, 471-481. [CrossRef]

95. Ramis, G.; Busca, G.; Lorenzelli, V. Low-temperature $\mathrm{CO}_{2}$ adsorption on metal oxides: Spectroscopic characterization of some weakly adsorbed species. Mater. Chem. Phys. 1991, 29, 425-435. [CrossRef]

96. Tabatabai, M.A. A Rapid Method for Determination of Sulfate in Water Samples. Environ. Lett. 1974, 7, 237-243. [CrossRef]

97. Zanella, R.; Giorgio, S.; Henry, C.R.; Louis, C. Alternative Methods for the Preparation of Gold Nanoparticles Supported on $\mathrm{TiO}_{2}$. J. Phys. Chem. B 2002, 106, 7634-7642. [CrossRef]

98. Menegazzo, F.; Signoretto, M.; Pinna, F.; Manzoli, M.; Aina, V.; Cerrato, G.; Boccuzzi, F. Oxidative esterification of renewable furfural on gold-based catalysts: Which is the best support? J. Catal. 2014, 309, 241-247. [CrossRef]

99. Brunauer, S.; Emmett, P.H.; Teller, E. Adsorption of Gases in Multimolecular Layers. J. Am. Chem. Soc. 1938, 60, 309-319. [CrossRef]

100. Barrett, E.P.; Joyner, L.S.; Halenda, P.P. The Determination of Pore Volume and Area Distributions in Porous Substances. I. Computations from Nitrogen Isotherms. J. Am. Chem. Soc. 1951, 73, 373-380. [CrossRef]

101. Kubelka, P.; Munk, F. Ein Beitrag Zur Optik Der Farbanstriche. Zeitschrift Technische Physik 1931, $12,593-601$.

102. Liu, D.; Fernandez, Y.; Ola, O.; Maroto-Valer, M.; Parlett, C.M.A.; Lee, A.F.; Wu, J.C.S. On the impact of Cu dispersion on $\mathrm{CO}_{2}$ photoreduction over $\mathrm{Cu} / \mathrm{TiO}_{2}$. Catal. Commun. 2012, 25, 78-82. [CrossRef]

103. Tahir, M.; Amin, N. Photocatalytic reduction of carbon dioxide with water vapors over montmorillonite modified $\mathrm{TiO}_{2}$ nanocomposites. Appl. Catal. B 2013, 142-143, 512-522. [CrossRef]

104. Braslavsky, S.E.; Braun, A.M.; Cassano, A.E.; Emeline, A.V.; Litter, M.I.; Palmisano, L.; Parmon, V.N.; Serpone, N. Glossary of terms used in photocatalysis and radiation catalysis (IUPAC Recommendations 2011). Pure Appl. Chem. 2011, 83, 931-1014. [CrossRef] 